\title{
Direito dos Investimentos e o Petróleo
}

\author{
Marilda Rosado de Sá Ribeiro ${ }^{1 \mathrm{e} 2}$
}

\section{Resumo:}

A exploração racional dos recursos naturais e energéticos representa tema de suma relevância para a Sociedade Internacional contemporânea. $\mathrm{Na}$ atual conjuntura econômica mundial torna-se imprescindível a conjugação de esforços de diversos atores para alcançar a finalidade comum consubstanciada no ideal do desenvolvimento sustentável. Tais fatores contribuíram para a o desenvolvimento de novas áreas do Direito, tais como o Direito dos Investimentos, cujo estudo e compreensão revelam-se absolutamente necessários tanto para os investidores e seus advogados como para os Estados-hospedeiros.

Palavras-chave: investimentos estrangeiros - recursos energéticos - soberania - expropriação.

\begin{abstract}
:
The rational exploration of natural and energetic resources has a fundamental meaning to contemporary International Society. Within the current world economic conjuncture, different kinds of economic agents join efforts to reach for the ideal of sustainable development. Such factors might have helped in the development of new fields of traditional law such as the Investment Law, whose study has become absolutely necessary not only for investors and their counselors but for the Host-States as well.
\end{abstract}

Keywords: foreign direct investments - energy resources - sovereignty - expropriation.

\section{A. Introdução}

Pretendemos neste artigo focalizar a renovação do interesse na regulação internacional dos investimentos no Direito Internacional Contemporâneo e a relevância do tema para os estudos sobre o petróleo e o gás. Os investimentos na indústria do petróleo, pela duração e risco envolvidos, são um paradigma das intempéries a que se sujeitam os investimentos diretos, de longo prazo, mais vulneráveis às oscilações e mudanças introduzidas pelos países hospedeiros em suas políticas.

A notável expansão do Direito Internacional no que afeta às relações entre países hospedeiros e investidores internacionais gerou um corpo denso do que pode ser considerado um novo Direito Internacional costumeiro, o qual emerge de um rico conjunto de fontes, tratados, estatutos, doutrina e decisões arbitrais. Tal direito, como bem comenta Andreas F. Lowenfeld ${ }^{3}$, não é monolítico, e nem poderia sê-lo. Convém lembrar que os tratados, mesmo quando não assinados pelo país hospedeiro, podem constituir fonte de Direito costumeiro. A

\footnotetext{
${ }^{1}$ Professora Adjunta de Direito Internacional Privado da Faculdade de Direito da Universidade do Estado do Rio de Janeiro.

${ }^{2}$ A autora agradece a colaboração dos seguintes alunos da UERJ: o Doutorando em Direito Internacional Bruno Almeida, dos mestrandos Rômulo Brillo e Marcos Martins, e dos graduandos Camila Viana, Felipe Almeida, Nícola Hargreaves, Larissa Toledo e Leandro Laurindo. Na fase inicial também colaborou Illana Meyer.

${ }^{3}$ LOWENFELD, Andreas F.. International Economic Law. New York: Oxford, 2002. p. 493.
} 
rapidez vertiginosa das mudanças na sociedade global também provoca a abreviação do tempo necessário à formação do costume. ${ }^{4}$

A sociedade contemporânea convive com um crescente fluxo de investimentos internacionais, em teias de crescente complexidade, que envolvem a presença global das sociedades transnacionais. Com a desconstrução nas cadeias produtivas, novos desafios se apresentam à visão jurídica da regulação desses investimentos por parte dos países hospedeiros. A tensão entre os dois pólos - Estado hospedeiro e investidor -, teve um efeito pendular ao longo da história, vislumbrando-se hoje um retorno do tema das nacionalizações e expropriações à ordem do dia no Direito Internacional.

Diversos internacionalistas têm focalizado esse complexo cenário de incertezas quanto às funções a serem desempenhadas pelo Estado territorial no "mundo em transformação", no qual há cada vez mais intensa interdependência econômica dos Estados e há maior liberdade e expressividade dos fluxos de capital e de mercadorias transfronteiriços.

A incorporação de novas dimensões, decorrentes do aumento da preocupação quanto a questões de elevado interesse comum da humanidade, como a proteção do meio ambiente e dos direitos humanos encontram eco no escopo desses novos estudos ${ }^{5}$

Registre-se que a questão dos limites impostos pelo Direito Internacional aos Estados, com relação aos interesses econômicos no âmbito de sua jurisdição territorial, alimentou muitas das controvérsias entre os países exportadores e importadores de capital.

As teorias tradicionais de proteção diplomática e responsabilidade do Estado passaram a ser confrontadas, na segunda metade do século $\mathrm{XX}$, com o princípio da soberania permanente sobre os recursos naturais, riqueza e atividades econômicas. ${ }^{6}$ A evolução na doutrina internacional levou alguns Estados a considerarem a regra da soberania permanente como uma norma peremptória de Direito Internacional. Efetivamente, esta é considerada por Brownlie como uma das "regras candidatas" a ter o status especial de $\underline{j u s} \underline{\operatorname{cogens}} .{ }^{7 \text { e } 8}$

\footnotetext{
${ }^{4}$ AMARAL JUNIOR, Alberto. O Direito de Assistência Humanitária e a Evolução dos Direitos Humanos: O Surgimento de um Novo Direito, in CASELLA,Paulo Borba et al Direito Internacional, Humanismo e Globalidade. São Paulo: Atlas, 2008. ver também PEREIRA, Luís Cezar Ramos Costume Internacional Gênese do Direito Internacional. Rio de Janeiro: Renovar, 2002.

${ }^{5}$ CANÇADO TRINDADE, Antonio Augusto, A Humanização do Direito Internacional, Belo Horizonte: Del Rey, 2006, p.3-409; CANÇADO TRINDADE, Antonio Augusto, A Pessoa Humana como Sujeito de Direto Internacional: A Experiência da Corte Interamericana de Direitos Humanos, in DIREITO, Carlos Alberto Menezes et al.. Novas Perspectivas do Direito Internacional Contemporâneo. Rio de Janeiro:Renovar, 2008, p.501. PEDROSO, Jorge. A internacionalização das National Oil Companies e o Direito Internacional. Dissertação de mestrado, UERJ, 2008.

${ }^{6}$ BUJALIC, Milan. Principles of International Development Law. Dordrecht: Martinus Nijhoff, 1986., p. 246247.

${ }^{7}$ SOARES, Guido Fernando Silva. Curso de direito internacional público. São Paulo: Atlas, 2002, v. 1. p. 6. Guido Soares leciona o alcance do princípio: "Trata-se da afirmação de haver no Direito Internacional normas
} 
A gênese da doutrina da soberania permanente sobre os recursos naturais é encontrada nas discussões preliminares sobre os direitos humanos no início da década de $1950 .{ }^{9}$ Isso porque, como bem esclarece Bernard Taverne, foi somente após a Segunda Guerra Mundial que as operações de produção de petróleo em áreas offshore ultrapassaram os limites do mar territorial e da jurisdição do Estado costeiro. A partir desse momento, deixou de haver consenso internacional quanto à extensão do mar territorial e, em consequência, quanto à extensão da soberania do Estado sobre sua plataforma continental, questões que tinham de ser resolvidas antes de a indústria poder se dirigir com confiança em direção ao alto-mar. ${ }^{10} \mathrm{O}$ conceito de soberania permanente sobre os recursos naturais foi bastante questionado pelos países industrializados, ${ }^{11}$ até se conseguir um consenso básico, ${ }^{12}$ após o fundamento obtido das grandes decisões arbitrais envolvendo contratos de petróleo. ${ }^{13}$

Thomas Waelde observa a relutância das tradicionais companhias da indústria do petróleo em se submeterem à arbitragem ou a processos judiciais entre elas, principalmente empresas frequentemente integrantes de joint ventures. ${ }^{14} \mathrm{O}$ mesmo autor destacava a mudança

que constituiriam um jus cogens, que se sobrepõem à vontade dos Estados, e não podem ser modificadas por dispositivos oriundos, seja nos tratados e convenções internacionais, seja nas normas consuetudinárias internacionais, seja, ainda, por estarem definidas como princípios gerais de direito."

${ }^{8}$ Entretanto, embora as posições mais radicais pudessem estar em consonância com o art. 64 da Convenção de Viena sobre os tratados, nesse particular, o próprio Brownlie diverge da extensão exagerada por vezes atribuída ao princípio. BROWNLIE, Ian. Principles of public international law. $2^{\text {nd }}$ ed. Oxford: Clarendon Press, 1973.

9 GARCIA-AMADOR, Francisco V. The emerging international law of development: a new dimension of international economic law. New York: Oceana Publications, 1990, p. 132. A respeito da associação do temário da soberania permanente sobre os recursos naturais e os direitos humanos, particularmente ao direito dos povos ao desenvolvimento econômico, ensina-nos Celso Mello que "o que mais nos interessa no princípio da soberania é especificamente a 'soberania sobre os recursos naturais', por ser ela que lida mais diretamente com o DI do Desenvolvimento." MELLO, Celso D. de Albuquerque. Direito internacional econômico. Rio de Janeiro: Renovar, 1993. p. 49.

10 TAVERNE, Bernard. Petroleum, industry and governments: an introduction to petroleum regulation, economics and government policies. The Hague; Boston: Kluwer Law International, 1999. p. 275-276.

${ }^{11} \mathrm{Na}$ sua $13^{\mathrm{a}}$ sessão, a ONU resolveu, entre outras medidas, criar uma comissão sobre o assunto, que convergiu, após intensos estudos, para a Declaração sobre a Soberania Permanente em Relação aos Recursos Naturais, que foi adotada na Assembléia Geral como a Resolução 1.803, de 14 de dezembro de 1962. Essa resolução representou uma posição conciliatória, tendo sido adotada por 87 votos a favor, 2 contra e 12 abstenções. BUJALIC. Op. cit., p. 251.

${ }^{12}$ A questão da soberania sobre os recursos naturais passou a ser considerada também um "direito ao desenvolvimento", demonstrando uma natureza político-jurídica, como o direito dos Estados de apropriar-se de propriedade de estrangeiros em seu território, na tradição de Grócio. GARCIA-AMADOR, F.V. The Energing International Law of Development: A New Dimension of International Economic Law. New York: Ocean, 1990. p. 123.

${ }^{13}$ HIGGINS, Rosalynn. International law and the avoidance containment and resolution of disputes: general course on public international law. Recueil des Cours, Collected Courses. Leiden: Martinus Nijhoff Publishers, v. 230, issue V, p. 9-342, 1991. Académie de Droit International de la Haye / Hague Academy of International Law.

${ }^{14}$ Segundo Thomas Waelde, essa tendência continuará existindo entre as grandes empresas petrolíferas. Ele já previa que, com a inserção de novos players, ou seja, pequenas empresas da Ásia, Rússia e América Latina, originadas dos processos de privatização, essa "club mentality” da indústria do petróleo deveria superada com a integração desses novos players. In The role of arbitration in the globalisation of energy markets (introduction to future book on international energy arbitration). Center for Energy, Petroleum and Mineral Law and Police 
na relação entre empresas estrangeiras e Estados hospedeiros, na medida em que, tradicionalmente, as divergências diziam respeito à nacionalização de recursos pelo Estado hospedeiro e, na década de 1990, relacionavam-se com o exercício de poderes regulatórios pela autoridade estabelecida após as privatizações. Com a nova onda do nacionalismo energético esse efeito pendular precisa ser revisitado. ${ }^{15}$

Nas décadas de setenta e oitenta do século passado, no plano do direito interno dos países receptores, houve um refinamento maior nas legislações quanto aos investimentos estrangeiros. A regulação do ingresso e da saída de capitais estrangeiros e sua implementação obedecem aos objetivos de longo e médio prazos, fixados pelo Estado por via legislativa. Esses objetivos, segundo Luiz Olavo Baptista ${ }^{16}$, variam no curso do tempo, sendo objeto de ajustes gradativos e de menor escopo, via de regra, pelos órgãos de controle ou fiscalização. Há que calibrar essas mudanças de modo a manter o equilíbrio entre os dois pólos da relação jurídica.

O desafio desse balanceamento marcou as discussões que envolviam a criação da Nova Ordem Econômica Internacional. Cada vez mais os investimentos foram assumindo novas formas e os países hospedeiros reavivaram sua demanda pelos investimentos internacionais, buscando também novas modalidades de atração e fidelização do capital estrangeiro.

Ao longo do século XX aumentou a demanda por um sistema efetivo de ordem e de direito global, que permitam aos negócios internacionais instrumentos legais que propiciem confiança. Os Estados devem organizar suas competências segundo a boa governança ('good governance'). Ademais, o controle legal do poder econômico, público ou privado, pode evitar distorções à competição. ${ }^{17}$ Dentre as novas abordagens sobre a questão, notadamente o estudo da regulação da atuação dos agentes econômicos em escala global, cabe realçar a prevenção e punição de práticas desleais que possam ser cometidas no comércio internacional. Novas

Internet Journal, Dundee, $\quad$ v. $\quad 6, \quad$ n. $\quad 18, \quad 1997 . \quad$ Disponível $\quad$ em <http://www.dundee.ac.uk/cepmlp/journal/html/vol6/article6-18.html >. Acesso em: 05 abr. 2006.

15 Ibid. Sobre o assunto, ver ainda RIBEIRO, Marilda Rosado de Sá. Sovereignty over Natural Resources Investment Law and Expropriation: The case of Bolivia and Brazil. The Journal of World Energy Law and Business, Oxford Journals, Vol 2, number 2, July 2009.

${ }^{16}$ BAPTISTA, Luiz Olavo, Investimentos Internacionais no Direito Comparado e Brasileiro. Porto Alegre: Livraria do Advogado, 1998, pp. 17-18.

${ }^{17}$ WAELDE, Thomas. "Changing Directions for International Investment Law in Global Economy an Overview of Selected Issues”. In CEPMLP Internet Journal, vol. 4, 1999. Disponível em: www.dundee.ac.uk/cepmlp. 
propostas em análise merecem menção, na projeção de uma ordenação internacional para o direito da concorrência. ${ }^{18}$

No plano do direito internacional, dentre as fontes doutrinárias e normativas, cabe destacar os princípios que regem a Novíssima Ordem Internacional, a qual chega a formar, na época contemporânea, um novo direito transnacional ou cosmopolita, que consagra valores de boa-fé, respeito aos direitos individuais e novos balizamentos para o exercício do poder Estatal. Tal Novíssima Ordem Internacional aponta mudanças na correlação de forças com os investidores, e já apresentou também novos cenários para as empresas transnacionais e para a regulação de sua atuação, nascida a partir da década de $1970 .{ }^{19}$

A recepção dessa Novíssima Ordem Internacional pelo ordenamento jurídico brasileiro materializou-se, como não poderia deixar de ser, no bojo das transformações do Direito Constitucional pátrio, inspirado nos valores do assim denominado novo constitucionalismo. Nessa perspectiva, colhemos subsídios não somente no arcabouço normativo, mas também nas passagens emblemáticas de nossa melhor doutrina, que dão o foco interpretativo dos princípios que constituem a base de nosso ordenamento jurídico, com destaque para os princípios da segurança jurídica, o respeito aos direitos adquiridos e a não retroatividade, bem como à boa-fé objetiva e à confiança legítima.

Vistas de outra forma, tais transformações provocaram verdadeiras rupturas institucionais no Estado e no Direito, como: mundialização da economia (internacionalização dos mercados); desconcentração do aparelho estatal (privatização e desregulamentação dos direitos sociais ); internacionalização do Estado; formação de blocos regionais e tratados de livre comércio); desterritorialização e reorganização do espaço da produção (substituição do paradigma fordista pelo toyotista); fragmentação das atividades produtivas nos diferentes territórios e continentes (concentração dos investimentos das empresas transnacionais em países com legislações favoráveis); e expansão de um direito paralelo ao dos Estados (lex mercatoria $)^{20}$.

Os processos apontados sinalizaram para uma revisão do conceito de soberania e para extremos de questionamento em torno do papel do Estado, chegando alguns autores a

\footnotetext{
${ }^{18}$ IMMENGA, Ulrich. Le droit de la concurrence dans l'économie globale. In: Philosophie du Droit et Droit Économique. Quel Dialogue? Mélange en l'honneur de Gérard Frajat. France, Paris: Ed.Frison Roche, 1999. apud Rodrigues de Carvalho, Clarissa Maria Beatriz Peixoto Brandão , Direito Internacional da Concorrência O Antitruste no Comércio Internacional, p. 288

${ }^{19}$ FRIEDMAN, Thomas. World is Flat - A Brief History of the Twenty First Century. New York,: Farrar, Straus and Giroux, 2005.

${ }^{20}$ FARIA, José Eduardo O Direito em crise, pp. 10-11, apud SILVEIRA, Eduardo Teixeira, A Disciplina Jurídica do Investimentos Estrangeiro no Brasil e no Direito Internacional , São Paulo, ed. Juarez de Oliveira, 2002,p. 13.
} 
vaticinar o fim do Estado. João Eduardo Alves Pereira entende que no sistema internacional da atualidade convivem duas lógicas espaciais: a do estado territorial e das redes associadas a economia transnacionalizada.

Há ainda, segundo o referido autor, uma forte relação das empresas transnacionais com seus países de origem. Os fluxos econômicos do mundo globalizado precisam de pontos nodais e eixos das redes, sendo o Estado agente econômico impulsionador e promotor de grande importância para a economia mundial. A dinâmica nos acordos bilaterais de investimentos reflete esta equação: o ente estatal abre mão de parte da soberania para garantir o fluxo de investimentos, mas ao mesmo tempo deve garantir a preservação de determinados valores estratégicos de sua preservação ${ }^{21}$.

As novas propostas apresentadas pelos juristas internacionalistas da nova geração incluem a criação de uma estrutura multilateral e supranacional competente para a análise do antitruste global, eis que as práticas anticompetitivas somente não podem mais ser prevenidas e punidas localmente. Para tanto contribui a definição e de reconhecimento de um mercado relevante geográfico global . ${ }^{22}$

É preciso reconhecer, ainda, que a crise financeira dos mercados, eclodida em meados de 2008, provocou muitas medidas de socorro a instituições financeiras e comerciais antes consideradas inexpugnáveis e blindadas em relação a crises. A retomada da defesa de um Estado interventor na economia, como uma possível solução ao problema, mais uma vez ilustra um efeito pendular em matéria de regulação de investimentos .

\section{B. Sociedade Internacional e a ponderação de princípios: direito cosmopolita, constitucionalismo e direito administrativo global}

A ligação entre o Direito Cosmopolita, que contém os princípios e as regras sobre as relações entre os Estados, as organizações internacionais, os indivíduos e as empresas no

\footnotetext{
${ }^{21}$ PEREIRA, João Eduardo de Alves. Geopolítica e direito internacional no século XXI. Em Novas Perspectivas do Direito Internacional Contemporâneo: Estudos em Homenagem ao Professor Celso D. de Albuquerque Mello. Org: DIREITO, Carlos Alberto Menezes; TRINDADE, Antônio Augusto Cançado; PEREIRA, Antônio Celso Alves.. Rio de Janeiro: Renovar, 2008, pp. 871 e 872.

${ }^{22}$ Rodrigues de Carvalho, Clarissa Maria Beatriz Peixoto Brandão , Direito Internacional da Concorrência - O Antitruste no Comércio Internacional, p. 288
} 
espaço supra-nacional não estatal ${ }^{23}$ e o direito interno dos Estados é o conceito de cidadania multidimensional (constitucional, internacional e cosmopolita). ${ }^{24}$

O cosmopolitismo também corporifica uma percepção dos problemas em escala global, consagrado na visão holista dos direitos humanos, segundo a qual se integram as suas dimensões nacionais, internacionais e cosmopolitas- plasmando a idéia de cidadania multidimensional (constitucional, internacional e cosmopolita). ${ }^{25}$ Esse movimento indica uma ruptura de paradigma com o constitucionalismo tradicional dos séculos XVIII e XIX, que tinha como figura central o Estado. Já existe um movimento no sentido de se aplicar princípios e precedentes que carecem de força coercitiva porque não integram o ordenamento jurídico do respectivo Estado. Seu fundamento de validade, ou melhor, legitimidade, repousa no sistema internacional de proteção de direitos humanos e na Teoria da Argumentação ${ }^{26}$.

Tal nova dimensão do Direito é vocacionada para lidar com as candentes questões envolvendo os investimentos internacionais. Sobressai também a inter-relação entre a visão deste Direito Cosmopolita e a denominada Lex Mercatoria calcada na importância do comércio internacional para o desenvolvimento. ${ }^{27}$

As demandas envolvendo a expropriação foram sempre submetidas aos tribunais internacionais e decididas de acordo com o Direito Internacional, com o patrocínio das causas pelo Estado de nacionalidade do investidor. Essa abordagem tinha o lastro positivista de que apenas os Estados eram sujeitos de Direito Internacional. Essa perspectiva tornava conceitualmente difícil o relacionamento direto entre o Estado hospedeiro e o investidor. ${ }^{28}$ No entanto, a tendência que emergiu em anos recentes é a democratização do Direito

\footnotetext{
${ }^{23}$ TORRES, Ricardo Lobo. A Afirmação do direito cosmopolita, Novas Perspectivas do Direito Internacional Contemporâneo: Estudos em Homenagem ao Professor Celso D. de Albuquerque Mello. Org: DIREITO, Carlos Alberto Menezes; TRINDADE, Antônio Augusto Cançado; PEREIRA, Antônio Celso Alves.. Rio de Janeiro: Renovar, 2008, p. 924.

${ }^{24}$ TORRES, Ricardo Lobo. A Afirmação do direito cosmopolita, op. cit., p. 927.

${ }^{25}$ TORRES, Ricardo Lobo. A Afirmação do direito cosmopolita, op. cit., p. 933.

${ }^{26}$ Nesse sentido: “o neoconstitucionalismo - que significou uma virada na Teoria Constitucional - já consistiria um primeiro alinhamento com a globalização ao conferir uma maior abertura ao ordenamento constitucional, seja através da inclusão de uma pauta axiológica nas Constituições do pós-guerra através dos princípios, seja por meio das cláusulas abertas, prevendo o ingresso de novos direitos a partir das experiências do direito internacional.” STAMATO, Bianca. Constitucionalismo Mundial e o 'Intercâmbio Mundial entre Juízes'. In BARROSO, Luís Roberto (org). A Reconstrução Democrática do Direito Público no Brasil. op. cit., p. 736-737. $27 \mathrm{Na}$ mesma esteira, a afirmação de que o comércio internacional é fator determinante da cilização contemporânea e condição sine qua non da nova ordem econômica internacional. STRENGER, Irineu. Direito do Comércio Internacional e Lex Mercatoria. São Paulo: LTR, 1996, p. 45. Ver também SARMENTO, Daniel. "Interesses Públicos VS. Interesses Privados na Perspectiva da Teoria e da Filosofia Constitucional" In SARMENTO, Daniel (org.). Interesses Públicos versus Interesses Privados: Desconstruindo o Princípio de Supremacia do Interesse Público. Rio de Janeiro: Lumen Juris, 2005,

${ }^{28}$ NORTON, Patrick M. "A Law of the Future or a Law of the Past? Modern Tribunals and the International Law of Expropriation”. In The American Journal of International Law. Vol. 85, no. 3, 1991, pp. 494
} 
Internacional, que passou a ser aplicado também aos indivíduos, organizações e negócios, a melhor doutrina anuncia o processo de humanização desta disciplina. ${ }^{29}$

Os novos conceitos emergentes das transformações do Direito Internacional Público e da candente influência dos princípios de proteção da pessoa humana têm provocado impacto em todos os ramos do Direito. Esses preceitos, consagrados pelas reformas constitucionais ocorridas em diversos países nos últimos vinte anos, notadamente na América Latina, passaram a impregnar a metodologia operacional e interpretativa aplicável no mesmo sentido. A ponderação sobre o aspecto econômico propicia uma maior convergência entre o público e o privado, ampliada pela metamorfose pela qual passaram as diversas disciplinas internacionalistas. ${ }^{30}$

A Sociedade Internacional é hoje permeada por novas perspectivas jurídicas e filosóficas. Nesse contexto, Paulo Bonavides, que sintetiza a teoria dos princípios, identifica nove resultados já consolidados na fase do Pós-Positivismo, a seguir:

\begin{abstract}
"1. A passagem dos princípios da especulação metafísica e abstrata para o campo concreto e positivo do Direito. 2. A transição crucial da ordem jusprivatista para a órbita juspublicística. 3. A suspensão da clássica distinção entre princípios e normas. 4. $O$ deslocamento dos princípios da esfera da jusfilosofia para o domínio da Ciência Jurídica. 5. A proclamação de sua normatividade. 6. A perda de seu caráter de normas programáticas. 7 . O reconhecimento definitivo de sua positividade e concretude por obra sobretudo das Constituições atuais. 8. A distinção entre regras e princípios, como espécies diversificadas do gênero norma. 9. A total hegemonia e preeminência dos princípios que norteiam as demais normas." 31
\end{abstract}

Dois dos princípios basilares que orientam nossa análise são a segurança jurídica e a cooperação internacional. A segurança jurídica é tida como um dos fundamentos do Estado de Direito, em conjunto com a Justiça e o bem estar social. A base contratualista que originou uma das teorias sobre a gênese do Estado moderno assenta a democracia na cláusula comutativa: o Estado dá segurança, mas confere liberdade. Nos termos do art. $2^{\circ}$ da Declaração dos Direitos do Homem e do cidadão, a segurança é um direito natural e imprescritível. $^{32}$

\footnotetext{
${ }^{29}$ CANÇADO TRINDADE, Antonio Augusto, A Humanização do Direito Internacional ,Belo Horizonte, Del Rey, 2006, p.3-409; CANÇADO TRINDADE, Antonio Augusto, A Pessoa Humana como Sujeito de Direto Internacional: A Experiência da Corte Interamericana de Direitos Humanos, in DIREITO , Carlos Alberto Menezes et al. Novas Perspectivas do Direito Internacional Contemporâneo. Rio de Janeiro: Renovar, 2008, p.501.

${ }^{30}$ JAYME, Erik. Identité Culturelle et integration: le Droit International Privé Postmoderne. Recueil de Cours. Academie de Droit International de la Haye, Leiden, Holanda, NL, v. 251, p. 21, 1995. Apud ARAUJO, Nadia. O Direito Internacional Privado e a Proteção da Pessoa Humana, op. cit., p. 461.

${ }^{31}$ BONAVIDES, Paulo. Curso de Direito Constitucional. $9^{\text {a }}$ ed. São Paulo: Malheiros, 2000, p. 237- 253.

${ }^{32}$ BARROSO, Luís Roberto. Temas de Direito Constitucional, vol I. Rio de Janeiro: Renovar, 2001. p. 50.
} 
Outro princípio essencial na sociedade contemporânea é o da cooperação internacional. A própria lei da coexistência entre os Estados foi substituída por uma lei internacional da cooperação. Devemos, no entanto, ter presente a noção de que a cooperação internacional, de certa forma, pode encerrar uma antinomia com o conceito de soberania, por exigir restrições a esta. ${ }^{33}$

Em outros estudos, procuramos demonstrar esse paradigma de cooperação e suas atuais mutações na área petrolífera. ${ }^{34}$ Nesta, ficam patentes os paralelismos entre os diversos níveis de cooperação possível entre as empresas, os Estados e as organizações internacionais, em diversidade de combinações de atores e procedimentos.

A cooperação é uma necessidade imperiosa para a própria sobrevivência da humanidade, oposta à atitude de competição predatória entre os Estados na disputa por reservas petrolíferas, verdadeira ameaça à paz. Na área petrolífera, as desigualdades e assimetrias estão na base das transações comerciais, e também aduziram as vulnerabilidades de todos os agentes. A procura por políticas alternativas para gerir a interdependência entre tantas partícipes torna-se imperiosa.

Há um anseio difuso no sentido de uma nova ponte entre a visão internacionalista e o exercício da atividade administrativa, não como exclusiva da seara doméstica estatal ou exercida, excepcionalmente, por entidades interestatais com alto nível de integração, tal como a União Européia. A visão restritiva dessa convergência esteve limitada pela sempre alegada razão da ausência de caráter cogente internacional.

Esta nova perspectiva se ampara no rápido crescimento dos regimes regulatórios internacionais e transnacionais, integrados por componentes e funções administrativos. Exemplifica-se tal assertiva com a existência de densa regulação na esfera econômica, a partir da atuação da OCDE, da OMC, do FMI, entre outros. Neste diapasão, oportuna a tese de Clarissa Maria Beatriz Peixoto Brandão Rodrigues de Carvalho sobre o Direito Internacional da Concorrência - O Antitruste no Comércio Internacional ${ }^{35}$, na qual são focalizadas , entre outros temas correlatos, as empresas transnacionais e seu papel no comércio internacional, para as quais afinal os Estados abrem suas fronteiras e o acesso aos seus mercados. São elas as beneficiárias imediatas da redução e liberação tarifária dos produtos, negociadas pelos Estados em foros internacionais, como, por exemplo, na OMC. Assume relevância o estudo

\footnotetext{
${ }^{33}$ MELLO, Celso D. de Albuquerque. Direito Internacional Econômico. Rio de Janeiro: Renovar, 1993.

${ }^{34}$ RIBEIRO, Marilda Rosado. Cooperação Internacional. Revista da Faculdade de Direito da UERJ, no prelo.

${ }^{35}$ Op. cit., p. 288
} 
das políticas comerciais protecionistas empreendidas pelos Estados, inobstante as obrigações assumidas pelos mesmos no sistema comercial mundial.

Benedict Kingsbury, Nico Krisch e Richard B. Stewart notam que padrões de governança global estão sendo construídos por um incipiente Direito Administrativo Global. Tal ramo do direito, contudo, não se encontra ainda unificado, nem organizado sob uma disciplina jurídica ou prática. ${ }^{36}$

O advento de um Direito Administrativo Global se corrobora a partir da análise do vasto crescimento do alcance e das formas de regulação e administração transgovernamentais, voltadas para as consequências da interdependência globalizada em campos como segurança, assistência financeira a países em desenvolvimento, proteção ao meio-ambiente, regulação financeira e bancária, aplicação efetiva da lei, telecomunicações, comércio de produtos e serviços, propriedade intelectual, standards trabalhistas, e movimentos transfronteiriços de massas, incluindo-se os refugiados. Progressivamente, verifica-se que tais repercussões não podem mais ser tratadas de forma efetiva através de regulação doméstica ou medidas administrativas isoladas.

Esse processo é ainda mais agudo no âmbito dos blocos econômicos, nos quais há uma mitigação da autonomia de políticas internas dos países com a consequente necessidade de sua adequação aos fatores supra-nacionais. A antiga relação de comando e de obediência passa a ser substituída por consultas prévias mútuas, ensejando o diálogo e o respeito aos direitos básicos de ambas as partes, colocando-as numa verdadeira base contratual.

Alguns princípios legais básicos e requisitos de caráter material e procedimental do nascente Direito Administrativo Global fazem eco à abordagem conceitual dos estudos sobre investimentos internacionais e à massa crítica conceitual do Direito Internacional, coligida a partir das decisões arbitrais e recente doutrina internacionalista sobre a matéria. Assim, são apontados elementos-chave do padrão de conduta almejado pela prática administrativa global: (i) participação no procedimento administrativo e transparência ("Procedural Participation and Transparency"); (ii) razoabilidade nas decisões (“Reasoned Decisions”); (iii) revisão das decisões administrativas ("Review"); (iv) standards substanciais, como proporcionalidade, racionalidade entre meios e fins, vedação a medidas restritivas desnecessárias e respeito às legítimas expectativas ("Substantive standards: Proportionality, Means-Ends Rationality, Avoidance of Unnecessarily Restrictive Means, Legitimate Expectations”); (v) a exceção das

\footnotetext{
${ }^{36}$ KINGSBURY, Benedict; KRISCH, Nico; STEWART, Richard B., The Emergence of Global Administrative Law, Research Project on Global Administrative Law, NYU School of Law, Institute of International Law and Justice em conjunto com o Center on Environmental and Land Use Law, 2005, p. 15-18.
} 
imunidades dos Estados (“Exceptions: Immunities”); e (vi) as exceções referentes a regimes especiais para certas áreas sujeitas à regulação ( "Exceptions: Special Regimes for Certain Issue Areas"). ${ }^{37}$

Registre-se também, em outro nível, a tentativa de determinação de padrões de conduta que ajudam Estados e organizações internacionais a escolher seus parceiros dentre os que obedecem a suas normas. A natureza jurídica do "código de conduta" seria a de soft law, composta somente de recomendações ${ }^{38}$. Mas o problema, na concepção de Michel Virally não é somente teórico, quanto à sua natureza jurídica, mas também prático, o da sua eficácia $^{39}$. O incremento dos mecanismos de auto-regulação, têm várias fontes de reforço. Entre elas a maior demanda global, originada da sociedade civil organizada, por transparência e responsabilidade das empresas transnacionais em sua atuação. Há um consenso e torno de temas como o da responsabilidade sócio-ambiental, o da governança corporativa e o da cidadania corporativa. ${ }^{40}$

\section{O Direito Internacional dos Investimentos}

O Direito Internacional do Investimento (International Investment Law) consiste em um conjunto de standards emanados do Direito Internacional Econômico e princípios e regras específicas , incorporando-se eventualmente as leis dos países hospedeiros. ${ }^{41}$ Ele surgiu na primeira metade do século $\mathrm{XX}$, em resposta às necessidades do pioneiro investidor industrial, contemplando-o também como sujeito de Direito Internacional. ${ }^{42}$ Seu escopo abrange as relações entre os investidores e os Estados hospedeiros de investimentos, e passou

\footnotetext{
${ }^{37}$ KINGSBURY, Benedict; KRISCH, Nico; STEWART, Richard B., The Emergence of Global Administrative Law, Research Project on Global Administrative Law, NYU School of Law, Institute of International Law and Justice em conjunto com o Center on Environmental and Land Use Law, 2005, pp. 37-42.

38 ALMEIDA, Betyna Ribeiro, A Regulação não estatal das Corporações Transnacionais, op. cit., p. 39.

${ }^{39}$ VIRALLY, Michel, Les Cods de Conduite, Pour Quoi faire? In TOUSCOZ, Jean, Transferts de tecnologie, Societés Transnactionaleset Nouvel Ordre International, 1978, pp.210 e ss, apud MELLO, Celso, Direito Internacional Econômico, p.117.

40 RIBEIRO, Marilda Rosado de Sá, As empresas Transnacionais e os Novos paradigmas do Comércio Internacional , in Novas Perspectivas do Direito Internacional Contemporâneo: Estudos em Homenagem ao Professor Celso D. de Albuquerque Mello. Org: DIREITO, Carlos Alberto Menezes; TRINDADE, Antônio Augusto Cançado; PEREIRA, Antônio Celso Alves.. Rio de Janeiro: Renovar, 2008, p. 924.

e PEDROSO, Jorge. A internacionalização das National Oil Companies e o Direito Internacional. Dissertação de mestrado, UERJ, 2008

${ }^{41}$ DOLZER, Rudolf; SCHREUER, Christoph. Principles of International Investment Law. New York: Oxford University Press, 2008, p. 3.

42 RYAN, Cristopher M. Meeting Expectations: Assessing the Long Term Legitimacy and Stability of International Investment Law. University of Pensylvania International Law Journal, vol. 29:3, 2008, p.725.
} 
a ser gradualmente utilizado como singular arcabouço de referencia para a regulação de condutas soberanas.

O fenômeno da globalização com a correlata expansão do comércio internacional e dos fluxos de capital, potencializados pelos avanços na informática e telecomunicações, impõe complexa agenda aos Estados na Novíssima Ordem Internacional. É inegável seu impacto sobre as políticas econômicas e legislativas, em contrapartida à percepção de que o Estado perde poder frente à volatilidade do capital.

Essa perspectiva é necessária especialmente para os países em desenvolvimento, que precisam estar articulados com as tendências e princípios da sociedade internacional, sob pena de serem excluídos do mercado global. ${ }^{43}$

Segundo Luiz Olavo Baptista, o regime de investimentos estrangeiros se desenvolve em três planos: o do acesso do estrangeiro às atividades econômicas, o da liberdade de ele adquirir e dispor dos bens necessários para a sua atividade econômica e, finalmente, o da garantia dos direitos individuais que lhe forem concedidos no País. ${ }^{44}$ No que tange ao acesso, é importante lembrar a discricionariedade do Estado em permiti-lo, pois, como aponta Carmen Tiburcio, a regra geral da igualdade (dos estrangeiros) não se aplicaria aos chamados direitos econômicos. ${ }^{45}$

Tem sido articulada a criação de um conjunto de princípios para reger o Direito Internacional dos investimentos, a partir dos tratados bilaterais, regionais ou multilaterais e dos costumes internacionais. Estes devem ser dotados, preliminarmente, de alguns standards mínimos, como os que se sugere: (i) as cláusulas e as condições devem ser estabelecidas à luz do princípio da boa-fé; e (ii) sua amplitude deve ser constitucionalmente validada pelos ordenamentos jurídicos internos e compatível com o direito internacional. ${ }^{46}$

Segundo Nicolaas Schrijver ${ }^{47}$, tais standards são constituídas pelos seguintes postulados:

\footnotetext{
${ }^{43}$ GREGORY, Denise e BERARDINELLI, Maria Fátima. O Desenvolvimento de Ambiente Favorável no Brasil para a Atração de Investimento Estrangeiro Direto, 2005, p.4. Disponível em: http://www.cebri.org.br/pdf/238_PDF.pdf, acesso em 27/11/2009.

${ }_{44}$ BAPTISTA, Luiz Olavo, Investimentos Internacionais no Direito Comparado e Brasileiro. Porto Alegre: Livraria do Advogado, 1998, p. 17-18.

45 "Segundo o Pacto Internacional dos Direitos Econômicos, Sociais e Culturais, em vigor no Brasil, os países em desenvolvimento, levando em consideração os direitos humanos e a situação econômica nacional, poderão determinar em que medida garantirão direitos econômicos reconhecidos no Pacto àqueles que não sejam seus nacionais". TIBURCIO, Carmen. Participação de estrangeiros na mídia. apud DOLINGER, Jacob. Direito internacional privado: parte geral. 7.ed. Rio de Janeiro: Renovar, 2003.

${ }^{46}$ DOLZER, Rudolf; SCHREUER, Christoph. Principles of International Investment Law (Foundations of Public International Law). Oxford University Press, 2008, pp.7-8.

47 SCHRIJVER, Nicolaas Jan. Sovereignty Over Natural Resources: Balancing Rights and Duties in an Interdependent World. 1995, p.164.
} 
(i) respeito à lei interna do Estado hospedeiro: em princípio, um investidor estrangeiro tem de aceitar e respeitar as leis e costumes do país em que reside e investe;

(ii) vedação de tratamento ao investidor estrangeiro abaixo do mínimo exigido no âmbito internacional: o Estado hospedeiro deve garantir um padrão razoavelmente seguro e propício ao investidores;

(iii) possibilidade das medidas de expropriação: o Estado hospedeiro reconhecidamente pode interferir na propriedade privada, do investidor, desde que obedeça a certos requisitos do Direito Internacional.

Há, ainda, outros fatores de suma importância para balizar a atuação soberana do Estado hospedeiro. Dentre eles, dê-se destaque para a natureza e o real propósito da conduta estatal; (em que se busca relação racional entre o propósito da medida expropriatória e o tratamento conferido ao investidor estrangeiro); o nível da proteção e do risco que o Estado oferece (investigar se a medida foi direcionada especialmente a determinado investidor em conduta discriminatória que é, portanto, vedada); e o impacto desta medida na legítima expectativa do investidor, assegurada pelo Estado.

A correlação entre a legítima expectativa do investidor estrangeiro e a modificação unilateral das circunstâncias, encontrada no costume internacional analisado por Celso D. de Albuquerque Mello quanto ao estoppel, instituto de origem anglo-saxã já admitido na jurisprudência internacional consistindo em "uma exceção de não recebimento oponível a toda alegação que, ainda que seja conforme a realidade dos fatos, é inadmissível por ser contrária a uma atitude anteriormente adotada pela parte que faz a alegação”. Em outras palavras, o adágio "non concedit venire contra factum proprium". ${ }^{48}$

A visão crítica quanto ao direito dos investimentos questiona a legitimidade do seu processo e de sua suposta invasão ao domínio antes reservado ao direito nacional. ${ }^{49}$ Alguns autores viram nesse incipiente domínio a possibilidade de uma visão tendenciosa a favor dos países exportadores de capital, ou até da diplomacia do dólar e do imperialismo. ${ }^{50}$

\footnotetext{
${ }^{48}$ MELLO, Celso D. de Albuquerque. Curso de Direito Internacional Público, vol I. 14ª edição. Ed. Renovar. Rio de Janeiro, São Paulo, 2002. P. 300.

${ }^{49}$ DOLZER, Rudolf; SCHREUER, Christoph. Principles of International Investment Law. New York: Oxford University Press, 2008, p. 9.

50 SCHRIJVER, Nicolaas Jan. Sovereignty Over Natural Resources: Balancing Rights and Duties in an Interdependent World. 1995, p.163.
} 
Muchlinski $^{51}$ examina os mais diversos aspectos políticos envolvidos nesse tema, abrindo espaço para exame dos padrões substantivos de conduta, bem como o exame de precedentes de arbitragens realizadas ao longo das últimas décadas.

Do ponto de vista econômico, o investimento gravita em torno da noção de afetação de capital ou bens em uma atividade que assegure o seu retorno, acrescido de lucros ou outra espécie de remuneração ${ }^{52}$. No caso do investimento internacional ${ }^{53}$, feito pelo nacional de um Estado em outro, a percepção dos riscos assumidos pelo investidor exige uma perspectiva interdisciplinar para sua análise.

Sob o prisma jurídico, três são os elementos essenciais dos investimentos: natureza, origem e destino ${ }^{54}$. Há que se atentar, contudo, para o caráter dinâmico e mutável do conceito, em razão da influência que exercem os interesses perseguidos pelos envolvidos no tema (v.g. o investidor, o Estado da nacionalidade do investidor e o Estado receptor do investimento).

\section{Histórico}

O fluxo dos investimentos internacionais está relacionado à evolução do comércio internacional, desde os primórdios da navegação e das conquistas na América. O incremento dos investimentos se verificou com o início da expansão das multinacionais, no século XIX. ${ }^{55}$ São descritos dois principais ciclos, o primeiro deles entre 1870 e 1914, ocasionado pela nova dimensão de mobilidade financeira internacional. ${ }^{56}$

A primeira fase histórica dos investimentos não suscitava a proteção do investidor estrangeiro em face do Estado hospedeiro. No caso dos investimentos em estados não colonizados, os países exportadores de capital valiam-se da diplomacia para proteger os investimentos de seus nacionais no exterior. ${ }^{57}$ Nesse particular a doutrina Calvo, criada pelo

\footnotetext{
${ }^{51}$ MUCHLINSKI, Peter. Policy Issues In The Oxford Handbook of International Investment Law , Oxford, University Press, N. York, 2008, p. 3- 48.

52 BAPTISTA, Luiz Olavo. Investimentos Internacionais no Direito Comparado e Brasileiro. Porto Alegre: Livraria do Advogado, 1998, p.29.

${ }^{53}$ PUCCI, Adriana Noemi. “Arbitragem e Investimentos Estrangeiros" In: Revista Brasileira de Arbitragem $\mathrm{n}^{\circ}$ 02, junho/ 2004, p. 14

${ }^{54}$ SORNARAJAH, M. The International Law on Foreign Investment. Cambridge University Press, 2004 , p.9. Na mesma linha, Denis Borges Barbosa vê três ângulos na definição de capital estrangeiro: o subjetivo, o objetivo o de finalidade, conferir BARBOSA, Denis Borges. Direito de Acesso ao capital estrangeiro, Rio, Lúmen Iuris,1996, p. 78.

55 VIDIGAL, Geraldo de Camargo et al. Panorama Jurídico-Econômico dos Investimentos Transnacionais: análise crítica. In CASELLA, Paulo Borba et al.. Direito Internacional, Humanismo e Globalidade: Guido Soares. São Paulo: Atlas, 2008, pp. 600-601.

56 DOLZER, Rudolf; SCHREUER, Christoph. Principles of International Investment Law. New York: Oxford University Press, 2008, p. 1.

${ }^{57}$ SORNARAJAH, M. The International Law on Foreign Investment. Op.cit, p.19.
} 
jurista argentino Carlos Calvo, almejava afastar a proteção diplomática em favor dos investidores estrangeiros. Consoante tal doutrina, dever-se-ia negar a possibilidade de responsabilização do Estado hospedeiro por perda ou prejuízo sofrido pelo investidor em decorrência de problemas internos ou guerra civil, tendo em vista que a indenização criaria um privilégio exorbitante em favor das nações mais ricas. ${ }^{58}$

A doutrina Drago, por sua vez, nasce no início do século XX para limitar o uso da força nas cobranças de dívidas contratuais ou de empréstimos obtidos pelos Estados, quando este se recusasse a submeter à arbitragem ou a cumprir laudo arbitral. ${ }^{59}$

Após a primeira Grande Guerra Mundial, consolidou-se no Direito Internacional o entendimento de que ao investidor deveria ser garantido o direito de acesso aos recursos descobertos com base em seus aportes financeiros e técnicos, em virtude do princípio de respeito à propriedade privada.

Assim, por meio de três precedentes emblemáticos - Mavrommatis, Alta Silésia e Usina de Chórzom - a Corte Permanente de Justiça Internacional assentou a noção da responsabilidade dos Estados por danos causados aos (investidores) estrangeiros em seus territórios, imputando aos entes soberanos a reparação dos danos até o momento necessário ao restabelecimento do status quo anterior ao ilícito. ${ }^{60}$

Com o advento da crise de 1929 o panorama dos investimentos internacionais é alterado e abre-se espaço para inúmeras expropriações que não incluíram qualquer indenização aos proprietários prejudicados. Desse pano de fundo emergiu a reação, que buscava assentar no Direito Internacional a garantia da imperiosa indenização imediata, adequada e efetiva a compensar o investimento estrangeiro expropriado. No cenário pósSegunda Guerra Mundial, há a retomada nos investimentos estrangeiros, com o fortalecimento das empresas transnacionais, que disseminam seus investimentos em países com mão de obra e matéria prima em abundância. Além disso, com a Guerra Fria, há uma intensificação do fluxo de capital dos países capitalistas e comunistas destinados a países do terceiro mundo, com o fito de nestes exercer influência. ${ }^{61}$

$\mathrm{Na}$ década de 1960 percebe-se o renascimento dos investimentos internacionais, marcado pelo aumento do fluxo de investimentos estrangeiros, sobretudo em países

\footnotetext{
${ }^{58}$ HERSHEY, Amos S. The Calvo and Drago Doctrines. In: American Journal of International Law. Vol. 1, 1907, p. 27.

${ }^{59}$ HERSHEY, Amos S. The Calvo and Drago Doctrines., op. cit, p.31.

60 VIDIGAL, Geraldo de Camargo. et al. Panorama Jurídico-Econômico dos Investimentos Transnacionais: análise crítica. In CASELLA, Paulo Borba. et al. Direito Internacional, Humanismo e Globalidade: Guido Soares. São Paulo: Atlas, 2008, p.602.

${ }^{61}$ SORNARAJAH, M. The International Law on Foreign Investment. Op.cit, p.22.
} 
subdesenvolvidos. Os investidores privados passaram a atuar com maior autonomia e independência em relação aos Estados Nacionais, bem como se utilizaram de técnicas de planejamento estratégico que os permitiram escolher e vislumbrar as melhores opções no mercado. $^{62}$

Em contrapartida, a década de 1970 é marcada pela retração dos investimentos, em função das crises do petróleo e da maior ingerência do Estado no gerenciamento de seus recursos naturais, com base no Princípio da Soberania Permanente sobre os Recursos Naturais, junto à Resolução 3201, que garante ao Estado o efetivo controle sobre seus recursos naturais.

A década de 1980, por sua vez, representou uma etapa de flexibilização jurídica dos países em desenvolvimento com vistas a atrair o capital estrangeiro para suas economias. A formação ou aprofundamento de diversos blocos econômicos, a exemplo da Comunidade Européia, do MERCOSUL e do NAFTA, com a criação de regras especiais para circulação de capitais, produtos, serviços e pessoas no âmbito desses blocos permitiu novos campos e horizontes para a pesquisa jurídica e regulação daí decorrente.

O auge do processo se deu na década de 1990, com as dificuldades dos países em desenvolvimento em quitarem suas dividas externas. Procura-se, então, adotar políticas de cooperação e de atração do capital estrangeiro, como mecanismo de crescimento e desenvolvimento econômico. Detectou-se uma quadruplicação dos investimentos estrangeiros entre 1990 e 2000, acompanhada de um crescimento vertiginoso dos tratados bilaterais de investimentos (BIT's), que passaram de 500 em 1990 a 2000 no ano de 2000 e de 2500 em 2005.63

Esse expressivo número de 2.500 BIT's ratificados por mais de 170 países do mundo permitiu a standardização relativa desses modelos, que têm algumas cláusulas principais: (i) tratamento justo e eqüitativo; (ii) proteção completa; (iii) não-discriminação; (iv) tratamento nacional; (v) tratamento da nação mais favorecida; (vi) garantias relativas aos casos de nacionalização elou desapropriação; (vii) garantias relativas a repatriação de capital $e$ remessa de lucros ao exterior. ${ }^{64}$ Em formulação análoga, são apontadas as seguintes disposições: (i) escopo de aplicação; (ii) condições para a entrada do investimento estrangeiro; (iii) padrão de tratamento dos investimentos estrangeiros (iv) transferências

\footnotetext{
${ }^{62}$ Nesse sentido: RABELLO, Gabriela Sampaio. Investimento Internacional e do Direito Econômico. In Revista de Direito Internacional Econômico, no 9, São Paulo, 2004, p. 90.

${ }^{63}$ DOLZER, Rudolf; SCHREUER, Christoph. Principles of International Investment Law. New York: Oxford University Press, 2008, p. 2

${ }^{64}$ PUCCI, Adriana Noemi. “Arbitragem e Investimentos Estrangeiros”, op. cit., p. 17.
} 
financeiras; (v) condições operacionais para o investimento; (vi) proteção contra a expropriação; (vii) reparação das perdas; (viii) solução de controvérsias. ${ }^{65}$

Kenneth J. Vandevelde afirma que, independente dos Estados que os pactuam, as disposições dos BIT's são, em grande medida, uniformes:

\begin{abstract}
"Several factors account for the uniformity among BITs. Most BITs between developed and developing states have been negotiated on the basis of models drafted by the developed states. The models themselves are similar because the drafters often drew upon certain common sources, such as the 1967 Organization for Economic Co-operation and Development (OECD) Draft Convention on the Protection of Foreign Property. ,66
\end{abstract}

Jeswald Salacuse e Nicholas Sullivan sintetizam que os três objetivos fundamentais dos Tratados Bilaterais de Investimento são a promoção, proteção e liberalização do investimento, sendo que estes últimos são conceitos absolutamente distintos, na medida em que:

\begin{abstract}
"Investment liberalization refers to facilitating the entry and operation of foreign investments in the host country. Investment protection refers to protecting the investment, once it has entered the country, from actions by governments and others that would interfere with investor property rights and the functioning of the investment in general. "67
\end{abstract}

Vandevelde assevera que os BIT's têm grande potencial para promover o incremento dos fluxos de investimentos estrangeiros, pois contribuem para a redução do risco político inerente à atividade econômica em outras jurisdições e tentam estruturar a proteção do investidor estrangeiro, a fim de evitar a expropriação sem a devida compensação, mudanças cambiárias danosas, o tratamento discriminatório pelo Estado-hospedeiro e outras formas de prejuízo à parte privada. Eles também sinalizam um compromisso em futuramente honrar com as obrigações assumidas. ${ }^{68}$

A partir de decisões envolvendo BIT's e casos relacionados ao NAFTA foram feitas análises sobre o padrão de conduta um padrão justo e equitativo ali consagrado, é válida a pergunta se tal padrão de tratamento mínimo é o mesmo da tradição do Direito Internacional

\footnotetext{
${ }^{65}$ SALACUSE, Jeswald W.; SULLIVAN, Nicholas P. "Do BIT's Really Work?: An Evaluation of Bilateral Investment Treaties and Their Grand Bargain" In Harvard International Law, vol. 46, n.1, Winter 2005, pp. 6 e 7.

${ }^{66}$ VANDEVELDE, Kenneth J. The Economics of Bilateral Investment Treaties. In Harvard International Law, vol. 41, n.2, Spring 2000, p.3. Veja-se a opinião do autor, mais especificamente sobre a relação entre a cláusula de nação mais favorecida ("most favored nation") e os tratados que estabelecem zonas de livre comércio. Como exemplo temos o teor do art. II (10) do Tratado de Investimento entre os Estados Unidos e a Estônia. ("The most-favored nation provision of this Treaty shall not apply to advantages accorded by either party to nationals or companies or any third country by virtue of ...that Party's binding obligations that derive from full membership in a free trade area or customs union....")

${ }^{67}$ SALACUSE, Jeswald W.; SULLIVAN, Nicholas P. "Do BIT's Really Work?: An Evaluation of Bilateral Investment Treaties and Their Grand Bargain" In Harvard International Law, vol. 46, n.1, Winter 2005, p.64.

${ }^{68}$ VANDEVELDE, Kenneth J. The Economics of Bilateral Investment Treaties. Op. cit, pp. 8 e 9.
} 
costumeiro ou se há um conjunto independente e novo de obrigações. Decisões no âmbito do NAFTA, entenderam que o tratamento justo e equitativo em nada excederia as garantias já contempladas pelo Direito Internacional costumeiro. ${ }^{69}$

Jean Kalicki e Suzana Medeiros analisam os dispositivos de diversos BIT's no âmbito do ICSID, concluindo que a cláusula de tratamento justo e equitativo ("fair and equitable treatment") comporta certa ambiguidade, como se lê, verbis:

\begin{abstract}
"Despite the growing importance of the fair and equitable treatment standard, its content and parameters remain ambiguous, uncertain, and subject to debate. Various factors contribute to this uncertainty and lack of uniformity. First, the text of fair and equitable treatment provisions in investment treaties varies considerably. Second, the standard itself is expressed in abstract and subjective terms, such as fairness and equity. Third, the meaning given to the standard often depends on the specific circumstances of each case. Finally, and inherent in the arbitral system, the fact that decisions of one tribunal regarding the contours of the standard are not binding upon the next, even where treaty text is identical or similar, contributes to the lack of uniformity.",70
\end{abstract}

Pode-se identificar um consenso crescente, em torno da necessidade de se estabelecer um corpo de regras transparentes, estáveis e previsíveis sobre investimentos internacionais, além dos tratados setoriais existentes. O escopo de mais segurança jurídica beneficiaria simultaneamente os países hospedeiros e os investidores, o que, conseqüentemente, proporciona um incremento ainda maior no volume dos investimentos estrangeiros. ${ }^{71}$

Por outro lado, o simples reconhecimento do vultoso crescimento do número de tratados de investimento já representa um alentado esforço no sentido da estruturação de uma moldura jurídica capaz de coadunar os interesses dos investidores e as necessidades dos Estados hospedeiros ${ }^{72}$.

\title{
Contratos com o Estado
}

Historicamente, demandas de expropriação eram direcionadas aos tribunais internacionais e regidas pelo Direito Internacional, apenas quando os Estados de nacionalidade do investidor patrocinavam as causas, na premissa de que somente os Estados

\footnotetext{
${ }^{69}$ DOLZER, Rudolf; SCHREUER, Christoph. Principles of International Investment Law. New York: Oxford University Press, 2008, p. 35 e 125.

${ }^{70}$ KALICKI, Jean e MEDEIROS, Suzana. Fair, Equitable and Ambiguous: What is fair and Equitable Treatment in International Investment Law ? ICSID Review - Foreign Investment Law Journal vol. 22, Number 1, Spring 2007, pp 25- 26.

71 AMARASINHA, Stefan D. Kokott, Juliane. Multilateral Investment rules revisited. In: Oxford Univesity Press, pp. 130-131.

72 SALACUSE, Jeswald W.; SULLIVAN, Nicholas P. "Do BIT's Really Work?: An Evaluation of Bilateral Investment Treaties and Their Grand Bargain” In Harvard International Law, vol. 46, n.1, 2005, p. 6.
} 
poderiam ser sujeitos de Direito Internacional. ${ }^{73}$ Entendia-se, assim, que a lei internacional aplicável era somente de Estado para Estado, o que dificultava a criação de uma relação direta entre o Estado que expropriava e o investidor estrangeiro prejudicado. ${ }^{74}$

Torna-se, portanto, atual o tema dos "Contratos com o Estado", que há décadas atrai o interesse da doutrina internacional. Nesse escopo são incluídos não somente os aspectos atinentes à execução dos contratos, mas também às fases preliminares da contratação. Celso Mello, em artigo intitulado "Contratos entre Estados e Empresas Estrangeiras", observa que o interesse por esse ramo decorre não apenas do fato de a prática desses contratos ter se tornado constante, mas por não existir regulamentação sobre a matéria no Direito Internacional positivo. A natureza jurídica desses contratos tem sido muito discutida, havendo autores que defendem a sua regulamentação pelo Direito Internacional Público, e outros que defendem a aplicação do Direito Interno. ${ }^{75}$

F.A. Mann teria sido o primeiro a sustentar a "internacionalização" desses contratos quando não existisse uma cláusula expressa fazendo referência a outro direito. Philip C. Jessup ${ }^{76}$ também pode ser alinhado entre aqueles que internacionalizam estes contratos, propondo, contudo, a criação de um novo ramo do Direito, o Direito Transnacional. Prosper Weil afirma que haveria a elaboração de um Direito Internacional dos Contratos ou Direito Contratual Internacional, que teria como fontes formais as convenções internacionais, o costume, as decisões judiciárias, a doutrina e os princípios gerais de direito e, como fontes materiais, o Direito Internacional e o Direito Interno. ${ }^{77}$

De acordo com o direito costumeiro, nenhum Estado tem a obrigação de aceitar investimentos estrangeiros em seu território, aplicados genericamente ou em um setor econômico específico. Dolzer e Schreuer ensinam que as prerrogativas de segregar e regulamentar os investimentos estrangeiros são uma expressão da soberania do Estado, da qual decorre, similarmente, a capacidade de celebrar tratados com outros Estados. ${ }^{78}$

Segundo Celso Mello, o Direito Interno deve prevalecer, uma vez que o interesse público do Estado receptor é mais importante do que o interesse comercial da empresa.

\footnotetext{
${ }^{73}$ MURPHY JR., Ewell. The Spiral of Time: A Historical Perspective on International Law Protection for Transnational Investment in the Twenty-first Century. In Currents International Trade Law Journal. Vol. VII (1), 1998, p.3.

${ }^{74}$ NORTON, Patrick M. "A Law of the Future or a Law of the Past? Modern Tribunals and the International Law of Expropriation”. In The American Journal of International Law. Vol. 85, No. 3, 1991, pgs. 494.

${ }^{75}$, Celso D. de Albuquerque. Contratos entre Estados e Empresas Estrangeiras. In: Estudos Jurídicos em Homenagem ao Professor Oscar Tenório. Rio de Janeiro: Uerj, 1977, pp 175-187, p. 180.

${ }^{76}$ JESSUP, Philip. Direito Transnacional. Rio de Janeiro: Fundo de Cultura, 1965, pp. 30-42.

${ }^{77}$ MELLO, Celso. Contratos entre Estados e Empresas Estrangeiras, op. cit, p. 181.

78 DOLZER, Rudolf; SCHREUER, Christoph. Principles of International Investment Law (Foundations of Public International Law). Oxford University Press, 2008, p.7
} 
Defende, ainda, que o Direito Internacional dos Contratos não pode vir a se tornar uma arma dos países ricos contra os países pobres. ${ }^{79}$

Assim, os contratos com o Estado, independentemente da terminologia - international agreement, quasi international agreement ou international economic agreement -, enfeixam temática pertinente a vários ramos do Direito, não sendo pacífica a questão sobre a que ramo do Direito eles estariam de fato submetidos. Quanto à escolha da lei aplicável aos contratos com o Estado, a principal tendência é a favor da aplicação da lei nacional do Estado, de acordo com o entendimento da Corte Permanente de Justiça Internacional (Haia). É inaceitável para um Estado o uso de outra lei de regência que não a territorial.

Tradicionalmente considerava-se patente o desequilíbrio econômico entre o Estado, em razão de seu poder legiferante, e a parte privada. Contudo, a equação é bem mais complexa na inter-relação de forças do que parece, pois esse desequilíbrio pode pender em favor da parte privada se figurarem as empresas transnacionais, cujo poder é muitas vezes superior ao dos próprios Estados. ${ }^{80 \text { e } 81}$

A questão da regência dos referidos contratos pela lei territorial está espelhada no caso clássico decidido pela Corte de Justiça da Haia, envolvendo os empréstimos sérvios e brasileiros (1929), onde se determinava que, na ausência de estipulação, assumia-se que as relações seriam regidas pela lei doméstica do Estado contratante, já que não se tratava de contrato celebrado pelo Estado na condição de sujeito de Direito Internacional. ${ }^{82}$

A existência de cláusulas de escolha de lei aplicável nos contratos com o Estado, já figurando nos contratos petrolíferos no final da década de 1920, foi consagrada na declaração proferida pelo Instituto de Direito Internacional na sessão de Atenas, 58, parte II, afirmando que os referidos contratos:

"poderiam ser regidos ou pelos vários sistemas jurídicos domésticos, ou pelos princípios comuns a esses sistemas, ou pelos princípios gerais do Direito, ou os princípios gerais aplicados nas relações econômicas internacionais, ou pela lei internacional, ou por uma combinação dessas fontes." 83

\footnotetext{
${ }^{79}$ Idem, pp. 183-184.

${ }^{80}$ Idem, pp 24-25.

81،“As empresas comerciais são hoje realmente uma força social atuante na vida internacional. O Direito não pode ignorar essa realidade. É de se lembrar que tais empresas são hoje muito mais poderosas do que inúmeros estados. É o caso do orçamento da General Motors, que é maior do que o orçamento de dezenas de estados em desenvolvimento." MELLO, Celso. Contratos entre Estados e Empresas Estrangeiras, op. cit., pp. 176-177).

${ }^{82}$ DOLINGER, Jacob. Direito Internacional Privado - Parte Geral. $9^{\text {a }}$ ed. Rio de Janeiro: Renovar, p. 87.

83 ANNUAIRE de L' Institut de Droit International, 195. Apud GARCIA-AMADOR, F.V. The Emerging International Law of Development: a New Dimension of International Law, op. cit., p. 167.
} 
De um total de 23 contratos publicados pela OPEP, em 1966-68, nove continham cláusulas de escolha de lei referindo os princípios gerais do Direito e o Direito Internacional, ${ }^{84}$ como aplicáveis para reger os referidos contratos.

As questões envolvendo investimentos privados externos foram inseridas nas próprias deliberações da Comissão sobre Soberania Permanente. ${ }^{85}$ Nos parágrafos $2^{\circ}$ e $3^{\circ}$ da Resolução ficou mais clara a problemática da intersecção entre a lei internacional e a lei territorial do que na própria Resolução 3.281, de 1974, da Carta de Deveres e Direitos Econômicos dos Estados. $^{86}$

\section{A Relação entre o Direito dos Investimentos e a Soberania}

O Direito dos Investimentos encoraja uma releitura do conceito de soberania na medida em que o Estado, ao regular setores da economia, deve observar os tratados multilaterais, bilaterais e os costumes internacionais sobre investimentos. Não se trata de defender que o Estado fica impedido de impor medidas de nacionalização, desde que obedecidos, sempre, os standards mínimos de proteção aos investidores, dentre eles: (i) $o$ tratamento justo e equitativo dos investimentos estrangeiros e (ii) o amplo acesso à justiça. $\mathrm{O}$ primeiro é previsto em grande parte dos tratados bilaterais e multilaterais de investimento e é geralmente invocado na superveniência de conflitos, enquanto o segundo se refere tanto aos procedimentos adotados perante os tribunais do Estado hospedeiro quanto aos conduzidos pela arbitragem, indo desde a instauração da lide até a prolação de sentença.

A nacionalização consiste, basicamente, em uma decisão discricionária e automática do Estado (ou outro ente de direito público) de transferência de propriedade ao seu domínio. Normalmente, tem inspiração em motivos políticos, econômicos ou sociais, e não se confunde com ato confiscatório, de caráter punitivo. Para que seja exercido regularmente, o direito do Estado de nacionalizar subordina-se a determinadas condições, tais como:

(i) ter como motivação o interesse público, bem como motivos de ordem política e socioeconômica;

(ii) ater-se ao principio da não-discriminação e da vedação ao confisco; e

(iii) indenizar de modo justo e equitativo aquele que sofreu dano com a medida.

\footnotetext{
${ }^{84}$ Idem, p. 169.

${ }^{85}$ Idem, p. 159.

${ }^{86}$ Idem, pp 160-161.
} 
À luz desses standards, as leis internas do país hospedeiro não podem impor tratamento diferencial e discriminatório aos investimentos e aos investidores estrangeiros. ${ }^{87}$

O exacerbado discurso da soberania, não raro, pode prejudicar o fluxo de investimentos em um determinado Estado hospedeiro. Com o fortalecimento das organizações internacionais, a formação de blocos econômicos, a criação de instituições supranacionais, busca-se a coexistência das soberanias de forma harmoniosa. ${ }^{88}$

Celso Mello observa que a noção de soberania é eminentemente histórica, no sentido de que sua interpretação tem variado no tempo e no espaço, de modo que tal atributo é encarado atualmente no seu sentido relativo, isto é, um feixe de competências que os Estados possuem, mas outorgado e limitado pela ordem internacional. ${ }^{89}$ Afirma, ainda o doutrinador que a tendência contemporânea da soberania é se consagrar como conceito formal, através do o Estado se encontra direta e imediatamente vinculado e subordinado ao Direito Internacional Público, sendo o seu conteúdo cada vez menor, tendo em vista a internacionalização da vida econômica, social e cultural. ${ }^{90}$

Focalizaremos os conceitos acima mencionados e a renovação do interesse no princípio da Soberania sobre os Recursos Naturais como justificativa às referidas práticas nacionalistas e expropriatórias, nos itens que seguem.

\section{D.1. Soberania sobre os Recursos Naturais}

A necessidade de convivência harmônica entre Estados dá a tônica para o caráter conciliatório que orienta o Direito Internacional. O sistema legal internacional está em constante evolução, não sendo reduto exclusivo de juristas, mas abrigando a política e a economia $^{91}$. Esta última, segundo Celso Mello, é o fator mais importante da vida internacional, pelo que faz sentido a expressão segurança econômica coletiva ${ }^{92}$.

O fato de que os Estados deixaram de ser os únicos sujeitos de Direito Internacional significou, de certa forma, uma democratização desse Direito, que passou a atingir indivíduos, organizações e negócios. A seguir, relevante lição: "Na nova sociedade universal

\footnotetext{
${ }^{87}$ AMARASINHA, Stefan D. Kokott, Juliane. Multilateral Investment rules revisited. In MUCHLINSKI, Peter. The Oxford Handbook of International Investment Law, Oxford, University Press, N. York, 2008, p. 122.

${ }^{88}$ HURTADO, Miguel de la Madrid. National Sovereignty and Globalization. In Houston Journal of International Law. Vol. 19, 1997, p.563.

${ }^{89}$ MELLO, Celso D. de Albuquerque. Curso de Direito Internacional Público. 12a ${ }^{\mathrm{a}}$ ed. Rio de Janeiro: Renovar, 2000, p. 425-427.

${ }^{90}$ MELLO, Celso D. de Albuquerque Mello. Direito Constitucional Internacional. Rio de Janeiro: Renovar, 2004. p. 121.

${ }^{91}$ WALLACE, Rebecca. International Law. $5^{\text {a }}$ ed. Nova Iorque: Sweet \& Maxwell, 2005, p. 4

${ }^{92}$ MELLO, Celso D. de Albuquerque. Direito Internacional Econômico. op. cit., p. 71.
} 
pode-se dizer que se está embaralhando o mapa do mundo”. Nele as principais forças produtivas "compreendendo o capital, a tecnologia, a força de trabalho e a divisão transnacional do trabalho, ultrapassam fronteiras geográficas, históricas e culturais, multiplicando-se assim as suas formas de articulação e contradição "93.

O direito dos povos à autodeterminação e a soberania permanente sobre seus recursos naturais é um dos fundamentos básicos do novo Direito Internacional. O direito dos Estados de escolher seu sistema econômico livremente é a emanação mais direta e não controvertida do princípio da igualdade soberana dos Estados no campo econômico.

Registre-se que a questão dos limites impostos pelo Direito Internacional aos Estados, com relação aos interesses econômicos no âmbito da sua jurisdição territorial, alimentou muita controvérsia e litígio entre os países exportadores e importadores de capital. As teorias tradicionais de proteção diplomática e responsabilidade do Estado passaram a ser confrontadas na segunda metade do século XX com o princípio da soberania permanente sobre os recursos naturais, riqueza e atividades econômicas ${ }^{94}$.

A gênese da doutrina da soberania permanente sobre os recursos naturais é encontrada nas discussões preliminares sobre os direitos do Mar $^{95}$. O consenso básico acerca da noção de soberania permanente teve lastro nas decisões arbitrais envolvendo contratos no âmbito da indústria petrolífera. Entretanto, mesmo após a Resolução 1.803, de 14 de Dezembro de 1962, pode-se dizer que ela ainda foi seguida por anos de agudização dos conflitos entre os dois pólos de interesse: os países exportadores de capital e os países importadores de capital. Não obstante, foi um dos pilares dos documentos firmados em 1974, para a proposta da Nova Ordem Econômica Internacional (New International Economic Order - NIEO).

Mencione-se que, em 1972, o conceito de soberania já havia sido reconhecido através do Princípio 21 da Declaração de Estocolmo, nos seguintes termos: "Principle of Sovereignty over natural resources and the responsibility not to cause damage to the environment of other states or to areas beyond national jurisdiction." ${ }^{96}$ Este princípio reforça a responsabilidade e obrigações de cuidado por parte dos Estados, em áreas além de sua jurisdição tradicional.

\footnotetext{
${ }^{93}$ IANNI apud BRANDÃO, Clarissa. "Concorrência e Desenvolvimento em Países Periféricos". In BARRAL, Welber e PIMENTEL, Luiz Otávio. Teoria Jurídica e Desenvolvimento. Florianópolis: Boiteux, 2006.

${ }^{94}$ BUJALIC, Milan. Principles of International Economic Law. Dordrecht: Martinus Nijhoff, 1986. pp. $245-247$.

95 GARCIA-AMADOR, The Emerging International Law of Development: a New Dimension of International Law, Op. cit., p.132.

${ }^{96}$ SANDS, Philippe. Principles of International Environmental Law. $2^{\mathrm{a}}$ ed. Cambridge: Cambridge University Press , 2003. p. 235-236.
} 


\section{D.2. Soberania, Expropriação e Compensação}

A discussão da questão da expropriação de bens de estrangeiros e as regras suas devidas compensações aos prejudicados se tornou uma praxe no âmbito internacional, embora a matéria tenha sido sempre objeto de controvérsia. As sucessivas tentativas de criação de uma lei internacional a respeito da matéria foram muito impactadas pela inovação da soberania natural sobre os recursos naturais. ${ }^{97}$

No âmbito do Direito Internacional muito se tem debatido em torno da definição e do grau do que pode ser considerado um Direito da Expropriação, de modo geral gradativamente ampliada como qualquer forma de redução da presença do investimento internacional ${ }^{98}$.

O clássico risco para os investimentos estrangeiros em um país hospedeiro é a possibilidade de esses investimentos sofrerem os efeitos da expropriação ou nacionalização pelo governo local. Uma subsidiária local de uma corporação transnacional é tanto uma empresa nacional, estabelecida e regida sob a lei do país hospedeiro, quanto uma sub-unidade de um sistema centralizado global.

Essa dualidade, inerente à estrutura do investimento estrangeiro direto, produz, do ponto de vista do investidor, tanto potenciais benefícios - como transferência de recursos e acesso a mercados - quanto custos - decorrentes da submissão às oscilações da economia e política locais ${ }^{99}$.

No século XX, inúmeras empresas estrangeiras perderam seus investimentos na produção de petróleo com a expropriação direta pelos governos do Irã, Kuwait, Líbia, México e Venezuela ${ }^{100}$. Outras formas de expropriação também ocorreram no Oriente Médio, principalmente através de renegociações. As controvérsias resultantes de grandes casos de expropriação, e as demandas arbitrais e judiciais decorrentes terminaram por gerar precedentes e posicionamento da doutrina internacionalista que criaram um pano de fundo conceitual para a análise de qualquer caso no século XXI.

Trata-se de reconhecer que, embora o respeito do Estado aos direitos adquiridos de estrangeiros seja um princípio básico do Direito Internacional, isso não significa que não

\footnotetext{
97 LOWENFELD,Andreas The Responsibility of Host States to Foreign Investors: Customary International Law", International Economic Law, New York: Oxford University Press, 2003.

98 FOLSOM, Ralph Haughwout; GORDON, Michael Wallace; JR. SPANGLE, John. Expropriation. In International business transaction: a problem-oriented coursebook. $2^{\mathrm{a}}$ ed. St. Paul: West Publishing CO., 1991. p. 880 .

99 KOBRIN, Stephen J. Foreign Enterprise and Forced Divestment in LDCs, In International Organization. Wisconsin: University of Wisconsin Press, vol. 34, n. 1, 1980, p. 65.

100 SMITH, Ernest, et al. Materials on International Petroleum Transactions. Colorado: Rocky Mountain Mineral Law Foundation, 2000, p. 338.
} 
possa haver violação aos direitos dele decorrentes, desde que tal fato se coadune com as necessidades e interesse geral que Estado soberano precisa garantir. ${ }^{101}$

Embora Oppenheim já afirmasse, em 1937, que um Estado sempre deveria respeitar a propriedade estrangeira ${ }^{102}$, Michael P. Darden salienta ser um princípio de Direito Internacional que os países hospedeiros realizem, em virtude de sua soberania, expropriações ou nacionalizações de investimentos, desde que sejam obedecidos certos requisitos: primeiramente, não deve haver nenhum tipo de acordo em sentido contrário; segundo, que os referidos atos se executem dentro de algumas "linhas mestras". São elas: (i) que os atos sejam realizados em virtude de interesse público, (ii) que sejam não-discriminatórios, e (iii) que sejam acompanhados de adequada e justa indenização ${ }^{103}$.

No mesmo sentido, a Resolução das Nações Unidas acerca da Soberania Permanente sobre os Recursos Naturais estatuiu quatro princípios básicos que deveriam permear a relação entre países desenvolvidos e países em desenvolvimento sempre quando os Estados se confrontassem com situações de expropriação:

(i) deveria ser paga uma compensação pela apropriação da propriedade estrangeira;

(ii) a compensação deveria ser paga de acordo com o Direito Internacional;

(iii) acordos de investimentos entre Estados e parceiros privados teriam, sobre essa questão, um efeito vinculante; e

(iv) cláusulas de arbitragem entre Estados e parceiros privados teriam, igualmente, um efeito vinculante ${ }^{104}$.

A percepção da lei aplicável à indenização realça a inter-relação orgânica e funcional existente entre a lei internacional e a lei territorial ${ }^{105}$. A "Fórmula de Hull" "106, muitas vezes

\footnotetext{
${ }^{101}$ Idem, p. 124-125. Como bem aponta R. Y. Jennings, nem o princípio do respeito aos direitos adquiridos, nem o princípio pacta sunt servanda podem ser considerados absolutos ou incondicionais em sua aplicação (JENNING, R. Y. State Contracts in International Law. In: The British Yearbook International Law, 1961, p. 177. Apud GAO, Zhiguo. International Petroleum Contracts: Current Trends and New Directions. Londres: Graham \& Trotman, 1994, p. 209).

${ }^{102}$ OPPENHEIM, L. International Law, vol. 1, n. 2, 5a ed. Lauterpacht, 1937.

${ }^{103}$ DARDEN, Michael P. International Due Deligence. Houston, Texas: Nuevo Energy Company [S.d.]. Part. 3, p. 3. Em palestra proferida em seminário ocorrido em Houston, Texas, Bernard Taverne afirma que os países signatários do Energy Charter Treaty de 1994 reconhecem os mesmos requisitos para a expropriação de investimentos estrangeiros, acrescendo o respeito ao devido processo legal, como se observa em TAVERNE, Bernard. op. cit., pp 316-317.

${ }^{104}$ SCHWEBEL, Stephen M. The Story of the UN's Declaration on Permanent Sovereignty over Natural Resources, ABA Journal, 463, 1963, p. 448.

${ }^{105}$ Idem, p. 126.
} 
invocada, estabelece que a indenização deve ser imediata, adequada e efetiva. No entanto, a análise histórica evidencia que, mesmo em contextos em que a fórmula foi adotada, a aplicação não ocorreu de forma literal ${ }^{107}$. Outras soluções, como as que buscavam uma "compensação justa" ou uma "compensação apropriada", surgiram, levando em consideração fatores como a habilidade do Estado de pagar o valor acertado.

Nem todas as nacionalizações comentadas pela doutrina internacional foram acompanhadas de uma compensação para as propriedades estrangeiras afetadas. Tal ocorreu tanto em países com processo de independência mais recente como em alguns em estágio mais avançado de desenvolvimento. ${ }^{108}$. Há, ainda, aqueles países que reduzem o valor da compensação paga à medida que desenvolvem a sua capacitação técnica. ${ }^{109} \mathrm{O}$ anseio de parte dos atores internacionais para consenso em torno de padrões para cálculo de uma compensação expedita, adequada e efetiva ("prompt, adequate and effective compensation"), não encontra, segundo alguns, amparo suficiente em decisões e leis internacionais ${ }^{110}$.

Por outro prisma são relatados os principais aspectos envolvidos: (i) justificação da expropriação sob a norma internacional, que deve ser pautada em razão de ordem pública; (ii) compensação do expropriado; e (iii) jurisdição para o processo de compensação - em regra, o que se tem hoje é a necessidade do esgotamento das vias jurisdicionais internas do país que expropria, o que leva, muitas vezes, a um rompimento de relações entre as duas nações envolvidas ${ }^{111}$.

$\mathrm{Na}$ abordagem clássica há dois estágios da expropriação: a intervenção e o confisco. A primeira é a posse física, na qual o negócio passa a ser controlado pelos interventores ou por estes supervisionados. ${ }^{112}$ Recentemente, entretanto, percebe-se que muitas vezes, a política

\footnotetext{
${ }^{106}$ A formula de Hull foi aplicada pela primeira vez no caso de nacionalização de empresas de petróleo norteamericanas no México, em 1936. O nome Hull era do secretário de Estado norte-americano Cordel Hull.

${ }^{107}$ LOWENFELD, Andreas. The Responsability of Host States to Foreign Investors: Customary International Law, op. cit, p. 414.

108 WILLIAMS, M. L. "The Extent and Significance of the Nationalization of Foreign-Owned Assets in Developing Countries, 1956-1972”, Oxford Economic Papers. Oxford: Oxford University Press, vol. 27. n. 2 , jul. 1975 , p. 270.

${ }^{109}$ Ibid., p. 272.

110 SHACHTER, Compensation for expropriation, apud FOLSOM, Ralph et al, op. cit, p. 891. Segundo o referido autor "[ $t$ ]he draft Restatement [of the Foreign Relations law of the United States] leaves no doubt that it considers the duty to pay just compensation to be a rule of international law", Como exemplos de decisões em que não se menciona a expressão adotada pela doutrina norte-americana mencionada, o autor cita o caso Chorzóm em que a Corte Permanente Internacional de Justiça fala em payment of fair compensation, enquanto na arbitragem Norwegian Shipowners Claims de 1922, aplica-se a expressão just compensation. Uma possível alternativa para a expressão just compensation é a appropriate compensation, apoiada por muitos estados na ONU, inclusive, pelo Estados Unidos, além de utilizado pela Corte de Apelações. Citando o juiz Jiménez de Aréchaga - primeiro Presidente da Corte Internacional -, o autor lembra que "the conception [of" "appropriate compensation'] brings in the principle of 'unjust enrichment'".

${ }^{111}$ FOLSOM, Ralph et al. op. cit, p. 883.

${ }^{112}$ FOLSOM, Ralph et al. op. cit., p. 884.
} 
econômica não faz intervenção direta, mas regulamenta de forma tão intensa a atividade empresarial, que se consuma uma forma indireta de intervenção. Nisso se inclui a chamada venda forçada, que é o uso de poderes coercitivos pelo governo, que podem variar desde a expropriação formal à imposição de dificuldades às operações de determinada empresa, de forma a induzir ao desinvestimento involuntário por meio de venda, que pode não refletir o valor de mercado da propriedade expropriada ${ }^{113}$.

Domke analisa as razões normalmente invocadas pelos Estados soberanos para a prática da expropriação: utilidade pública ("public utility"), ordem pública ("public purpose") ou dominante interesse público (“dominant public purpose”). Tais circunstâncias específicas se encontram em constituições de várias nações como forma de coibir abusos por parte do Executivo e Legislativo ${ }^{114}$.

Outra distinção relevante é feita quanto à expropriação por discriminação ou retaliação. M. Gordon entende que, nestes casos, não há embasamento em interesse público, o que não significa, necessariamente, a violação da lei internacional, pois há de existir uma justificativa para tanto. A nação discriminada pode estar dominando um mercado que o país agora necessita retomar; ou, o país hospedeiro pode alegar que sua economia está sendo prejudicada pela excessiva presença econômica do país estrangeiro em determinado setor. ${ }^{115}$

Sobre a proteção mínima a ser dispensada ao estrangeiro em face de expropriação, aduzem Rudolf Dolzer e Christoph Schreuer:

\footnotetext{
"The rules of international law governing the expropriation of alien property have long been of central concern to foreigners in general and to foreign investors in particular. Investors are destroyed in case the investment is taken without adequate compensation. On the level of customary international law, the minimum standard for the protection of aliens came to place limitations on the territorial sovereignty of the host state and to protect alien property. On the level of treaty law, all modern agreements on foreign investment contain specific provisions covering preconditions for and consequences of expropriation". 116
}

Estes autores apontam as três ramificações desenvolvidas pelo Direito Internacional a fim de regular o alcance e as condições ao exercício do poder expropriatório do Estado hospedeiro:

\footnotetext{
"Beyond the right of the host state to expropriate, the international law on expropriation has developed three branches, which regulate the scope and conditions of the exercise of this power. The first one defines the interests that will
}

\footnotetext{
${ }^{113}$ KOBRIN, Stephen J. op. cit., p. 68. KOBRIN, Stephen J. "Foreign Enterprise and Forced Divestment in LDCs", International Organization. Wisconsin: University of Wisconsin Press, vol. 34, n. 1, 1980, p. 65.

${ }^{114}$ DOMKE. Foreign Nationalizations apud FOLSOM. et al. op. cit., p. 885.

${ }^{115}$ GORDON. The cuban nationalization, the demise of foreign private property, Apud Folsom, et allie. Op. cit., p.886.

${ }^{116}$ DOLZER, Rudolf; SCHREUER, Christoph. Principles of International Investment Law. New York: Oxford University Press, 2008, p. 89.
} 
be protected. (...) Most contemporary treaties, in their provisions dealing with expropriation refer to 'investments'. (...) The second branch concerns the definition of an expropriation. While this matter raises no questions in case of a formal expropriation, the issue may acquire a high degree of complexity when the host state interferes with the rights of the foreign owner without a formal taking of title. (...) The third branch of the law on expropriation relates to the conditions under which a state may expropriate alien property. The classical requirements for a lawful expropriation are a public purpose, non-discrimination as well as prompt, adequate and effective compensation. In practice, the requirement of compensation has turned out to be the most controversial aspect". ${ }^{117}$

Por vezes os investimentos estrangeiros encontram maior resistência dos países hospedeiros, sobretudo quando a mineração e o setor petrolífero dominam a economia. Nesses casos a propriedade estrangeira passa ser vista como uma afronta à autonomia do Estado hospedeiro, podendo surgir ciclicamente o entendimento de que as medidas administrativas ou regulatórias não atingem o propósito de atender aos anseios do Estado hospedeiro de recuperar essa autonomia. A expropriação surge então como único instrumento viável para atingir esse fim $^{118}$.

A percepção tradicional da expropriação era a de medidas seguidas de uma mudança política maior, muitas vezes violenta ${ }^{119}$. Esse conceito passou por uma ampliação, eis que há formas menos evidentes de expropriação, como a expropriação regulatória e a creeping expropriation. ${ }^{120}$ Uma mudança radical da legislação de um país, bem como a alteração da regulação do setor petrolífero, pode significar uma modalidade de expropriação.

Folsom pondera que, muitas vezes, a política econômica do Estado hospedeiro não chega a consumar uma intervenção, porém, regulamenta de forma tão intensa a atividade empresarial, que tal comportamento poderia ser encarado como modalidade dissimulada de intervenção. $^{121}$

Cabe lembrar, ainda, que qualquer ato unilateral arbitrário do Estado relacionado a contratos de longa duração poderá ferir sua imagem de lugar confiável para investimentos estrangeiros $^{122}$. As cobranças e sanções virão não somente da fuga de capitais dos próprios investidores e do efeito perverso do custo país pelos ratings das agências internacionais.

\section{E. Investimentos Internacionais e Petróleo: Avaliação de Risco e Sanções}

\footnotetext{
${ }^{117}$ DOLZER, Rudolf; SCHREUER, Christoph. Principles of International Investment Law. New York: Oxford University Press, 2008, p. 90.

${ }^{118}$ KOBRIN, Stephen J. Op. cit., p. 71. KOBRIN, Stephen J. "Foreign Enterprise and Forced Divestment in LDCs", op.cit, p. 65.

${ }^{119}$ FOLSOM, Ralph et al, op. cit. p. 880.

120 WAELDE, Thomas. The Current Status of International Petroleum Investment Regulating, Licensing \& Taxing and Contracting, Dundee: CPMLP. Dezembro, 1994.

${ }^{121}$ FOLSOM, Ralph et al, op. cit., p. 884.

${ }^{122}$ GAO, Zhiguo. International Petroleum Contracts: Current Trends and New Directions, op. cit., p. 209.
} 
A avaliação do risco do investimento em um determinado Estado tem importância fundamental para o sucesso da empreitada. No âmbito da industria do petróleo, em especial, o denominado "populismo energético" gerou um ambiente de incertezas e certo temor por parte dos investidores. Alguns países latino-americanos produtores de petróleo passam a ser liderados por governos populistas, que permitem que os lucros advindos da commodity sejam destinados a propósitos políticos ou ao financiamento de projetos sociais, tendo ocorrido havido nesses casos, efetivo declínio dos investimentos estrangeiros e de novas tecnologias no setor, prevendo-se uma diminuição da oferta de energia.

Na América Latina, a rigidez na regulação no setor se dá em função de uma percepção crítica bastante difundida de que empresas transnacionais fizeram excessivos lucros às custas dos governos e, por isso, são necessárias políticas públicas capazes de regular fortemente a economia, principalmente, o setor energético.

Segundo Thomas Waelde:

\begin{abstract}
"o conceito chave para os investidores estrangeiros é 'risco político'. Na década de 1970, o risco político estava associado à expropriação ou à quase-expropriação (quebra nos contratos pelo Estado hospedeiro, regras que dificultam ou impedem a repatriação dos lucros). Atualmente, não apenas a expropriação na sua acepção da década de 1970 preocupa os investidores. Surge, hoje, um novo conceito: o 'risco político não convencional' como uma ameaça e um fator a ser considerado nos cálculos dos investidores. O risco de uma regulação excessiva e injusta se insere no conceito de risco político não convencional. ${ }^{\prime 123}$
\end{abstract}

Um caso recente bem ilustra o efeito pendular na abertura perante o capital estrangeiro. Trata-se do caso da Bolivia.

\begin{abstract}
"Many of the decisions and events that took place in some countries of the continent between 2006 and 2008 may be considered as a backward movement in the pendular effect that affects energy scenarios. In such context, the Energetic Populism, or Resource Nationalism that showed strong signs in Latin America in the past years might be identified more blatantly in some countries but also in scattered decisions and underlying trends in others. In the multitude of existing definitions of such recurrent nationalism, one can single out the "nations wanting to make the most of their endowment", but also identify an ideological bias that defends the strengthening of the role of State in the economy. As a general rule one could say this turn of the century has brought some events and legal developments that encourage the need for drawing some new lines and reshaping concepts to face the challenges posted by the changing legal environment. More recently the financial crisis in the global markets rendered more dramatic the ressurgence of the defence of the participation of the State in the economy." 124
\end{abstract}

\footnotetext{
123 WAELDE, Thomas. "Changing Directions for International Investment Law in Global Economy an Overview of Selected Issues". In: CEPMLP Internet Journal, vol. 4, 1999. Disponível em: www.dundee.ac.uk/cepmlp último acesso em 1/2/2010.

${ }^{124}$ RIBEIRO, Marilda Rosado de Sá. Sovereignty over Natural Resources Investment Law and Expropriation: The case of Bolivia and Brazil. Journal of World Energy Law \& Business, vol. 2, nº 2, Julho/2009.
} 
Uma acurada analise é encontrada em nova e multifacetada tese de autoria de Amalia Casas, na qual o estudo do caso boliviano presta-se para exemplificar, entre outras, as dificuldades de se regular uma área na que se lida com recursos estratégicos e com a propriedade estatal. A regulação com excessiva liberdade ao investidor é vista de maneira critica, notadamente se a riqueza econômica for para pouco se persistir o descontentamento social formulando a autora o desenho de :

\begin{abstract}
"um modelo com maior maturidade democrática que considere os aspectos positivos e negativos de ambos os modelos anteriores (liberal e estatizante). $O$ objetivo deve ser alcançar níveis de crescimento necessariamente acompanhados de distribuição de renda efetiva e da ampliação da base de consumo. O marco regulatório deve ser estável e deve garantir a agregação de novas reservas, que estimulem a competitividade e gerem atração de investimentos para o setor. Assim, a integração energética proposta na tese surgiria como um caminho eclético entre esses dois extremos: In Medio Stat Virtus. ",25
\end{abstract}

Portanto, se o agravamento da crise econômica e financeira mundial se somou ao ressurgimento do nacionalismo energético no continente Latino-Americano, especialmente após a repercussão mundial do caso Brasil-Bolívia, constata-se, independentemente das considerações valorativas, que essa tendência pode acarretar, por sua vez, no incremento do risco político, um fator estratégico na logística dos fluxos de investimentos internacionais para o continente.

\title{
E. A Perspectiva Brasileira
}

Não se teve no Brasil, historicamente, a tradição de indutores de investimento formalmente dirigido ao capital estrangeiro. Os sistemas de regulação e contenção de capital estrangeiro no país compreendiam dois principais mecanismos: (i) o de controle de fluxo de divisas, por meio do monopólio cambial e das restrições à remessa e ao retorno de capital, e (ii) o da tributação, por meio da instituição de impostos suplementares. Essas restrições objetivavam manter o controle público, nacional, sobre determinados segmentos da atividade econômica, principalmente aqueles em regime de monopólio. Tal cenário se modifica com a abertura da economia, na década de 90 , e a sucessiva onda de privatizações. ${ }^{126}$

Frise-se que a Constituição de 1988 consagra princípios que regem as relações internacionais do Brasil, permitindo falar, segundo Celso Mello, em um Direito

${ }^{125}$ DEL CORRAL, Amalia Del Carmen Casas de Las Peñas, A Integração Energética na América co Sul: Instrumentos Juridicos e Institucionais para Projetos Gasiferos Regionais tese apresentada como requisito à obtenção ao grau de doutor. Faculdade de Direito UERJ , dezembro 2009.

${ }^{126}$ BARBOSA, Denis Borges. Direito de acesso do capital estrangeiro. Direito do Desenvolvimento Industrial. Vol. I. Rio de Janeiro: Editora Lumen Juris, 1996. 
Constitucional Internacional, consubstanciado na tentativa de adaptar a Constituição Federal à ordem jurídica internacional que a sobrepõe.

De todos os dispositivos referentes à ordem internacional, cabe realçar a questão da nacionalidade da pessoa jurídica, consubstanciada no art. 171 da $\mathrm{CF}$, com a redação revista pela Emenda Constitucional no 6 de 1995. Resta evidenciada a consagração da nacionalidade da pessoa jurídica de acordo com o critério da constituição, associado ao critério da sede.

Considerando que não é o critério do controle da origem do capital que determina a nacionalidade das sociedades no direito brasileiro, pois este é meramente relegado às situações especialíssimas ressalvadas pelo próprio texto constitucional, as empresas constituídas no Brasil, e que aqui operam, estão abrigadas de qualquer forma de discriminação. É, portanto, incompatível com a nossa Carta Magna qualquer forma de discriminação contra o capital estrangeiro que não seja parte das exceções de áreas restritas ao controle por brasileiros que foram nela estabelecidas.

O Brasil como alvo estratégico e conveniente para investidores adquiriu impulso quando o risco-país caiu e o mesmo atingiu considerável posição no ranking de países receptores de investimentos em 2008. A tendência global de demanda pela energia, que em 2006 alcançou 84 milhões de barris/dia, é crescente. Espera-se atingir a escala de 120 milhões de barris/dia em 2030. Para tanto, o investimento necessário deve exceder US\$ 3 trilhões, dos quais $72 \%$ se destinam a exploração e produção de petróleo. Dentre tais previsões, o fato de que $55 \%$ dos investimentos estimados ocorrerão em países em desenvolvimento e que $50 \%$ da produção fora da OPEP será offshore leva o nosso país a uma boa perspectiva na atração de investimentos. $^{127}$

A ordem econômica na CF consagrou, no bojo das reformas da década de noventa, a retirada do Estado do exercício direto das atividades econômicas para assumir uma postura regulatória e fiscalizadora dos agentes do mercado ${ }^{128}$.

No setor petrolífero, a fiscalização ficou a cargo da Agência Nacional do Petróleo, Gás Natural e Biocombustíveis (ANP), cuja função regulatória foi conferida pela Lei 9.478/97 (Lei do Petróleo), do Ministério de Minas e Energia (MME), ao qual se vincula, e do Conselho Nacional de Política Energética (CNPE).

Nosso ordenamento não ficou imune ao fenômeno da convergência entre o direito público e o privado, tornando intercambiáveis alguns conceitos. Pode-se afirmar que, se por um lado o Direito Público se privatiza, este processo não anula a publicização do Direito

\footnotetext{
${ }^{127}$ Informações disponíveis no sítio da ANP: www.anp.gov.br

${ }^{128}$ RIBEIRO, Marilda Direito do Petróleo, op. cit.,p. 312.
} 
Privado, ou melhor, sua progressiva constitucionalização. Esse processo tem repercussão para a formação dos contratos, com a acentuação da importância do princípio da boa-fé, que passa a ser erigido a princípio geral de conduta consagrada na ordem jurídica brasileira.

Certos episódios ocorridos no Brasil mereceram uma análise diferenciada, como a suspensão da Oitava Rodada de Licitações conduzida pela ANP, em novembro de 2006, por força de decisões judiciais liminares face à proposição de duas ações populares. ${ }^{129}$

Em parecer de nossa lavra, elaborado em resposta à consulta realizada pelo Instituto Brasileiro de Petróleo, Gás e Biocombustíveis (IBP) sobre questões jurídicas concernentes a essa Rodada, conclui-se pela inconstitucionalidade da invalidação da Oitava Rodada, vez que não se encontram supridas, no caso em concreto, as condições necessárias à eventual revogação ou anulação, total ou parcial, do certame licitatório. Isso em contraponto a um conservadorismo latente capaz de justificar a invalidação de concorrências, com fundamento no poder discricionário do Estado ${ }^{130}$.

A decisão da Ministra Ellen Gracie corrobora a tese da responsabilidade do Estado perante os investidores ${ }^{131}$ :

\begin{abstract}
"O tempo é implacável com os países que relegam o planejamento estratégico a um plano inferior, certo que estamos a discutir questões relativas a materiais fósseis, que demandam constantes pesquisas, prospecções e altos investimentos. A União, por intermédio de seus órgãos competentes, a Agência Nacional do Petróleo, Gás Natural e Biocombustíveis - ANP e o Conselho Nacional de Política Energética CNPE, estabeleceu critérios, que julgou os melhores, para alcançar as metas de produção de petróleo e gás natural necessárias à sustentação do nosso modelo de crescimento a médio e longo prazos, critérios que se encontram, em princípio, dentro de um juízo eminentemente técnico, no qual está a interferir a decisão ora impugnada. Anoto, ainda, que a determinação prescrita na decisão ora atacada atinge o planejamento estratégico do país em relação à nossa matriz energética, o que certamente coloca em risco a própria segurança nacional, além de sinalizar negativamente aos investidores nacionais e estrangeiros, que estão a deslocar vultosas somas de dinheiro com o objetivo de suprir as imensas lacunas de um setor altamente tecnológico que demanda maquinário de última geração e pessoal especializado, de que não dispomos em escala suficiente, e que apresenta alto risco. Não se pode olvidar, ademais, que o capital sempre migra para os países onde estão as melhores oportunidades de investimentos e que lhe oferecem maior segurança, sobretudo jurídica.(...) Assim, os prejuízos à ordem econômica de nosso país dificilmente se reverterão ao final da tramitação desse processo, motivo que, por si só, legitima a suspensão imediata da decisão proferida pelo Juízo da $9^{a}$ Vara Federal da Seção Judiciária do Distrito Federal.
\end{abstract}

De se ressaltar, inclusive, que dois blocos exploratórios já haviam sido licitados na primeira etapa da Rodada, tendo sido obstada a conclusão e a assinatura do contrato de concessão, acarretando um prejuízo ainda maior ao licitante vencedor. Em síntese,

\footnotetext{
${ }^{129}$ http://www.brasil-rounds.gov.br.

${ }^{130}$ RIBEIRO, Marilda Rosado de Sá. Parecer sobre a Oitava Rodada de Licitações. In RIBEIRO, Marilda Rosado de Sá (coord.) Novos Rumos do Direito do Petróleo. Rio de Janeiro: Renovar, 2009, pp. 1-125.

${ }^{131}$ STF, SL no 176- DF, Relatora: Min. Ellen Gracie, publicado no DJU de 03/08/2007.
} 
sustentamos a infringência, no plano internacional, dos Princípios de Segurança Jurídica, Interdependência e Cooperação, e da Boa-fé Objetiva, além da frustração da confiança legítima dos participantes da Oitava Rodada de Licitações.

Ainda em sentido contrário ao da previsibilidade, a Resolução CNPE nº 6/2007 determinou a retirada de 41 blocos às vésperas da realização da Nona Rodada de Licitações, além da retirada do campo de Tupi, descoberto pela Petrobras ${ }^{132}$. Dessa forma foram introduzidos elementos de instabilidade e de preferência nacional, que o Brasil tinha, até então, evitado. $^{133}$

Detectamos, por conseguinte, a recente exacerbação e extrapolação de poderes do CNPE, erodindo-se o espaço deliberativo do órgão regulador. É necessária a cautela no exercício da missão institucional de cada um desses agentes do Estado e de Governo. A título de ilustração, destaca-se a pertinente lição extraída de Sérgio de Andréa Ferreira:

\begin{abstract}
"que uma autoridade - que seja competente, em termos legais - tem poder regulador não significa que tudo possa fazer a seu exclusivo critério; mas, inversamente, seu comportamento estará sempre sob o controle de outras autoridades, inclusive a judicial, cuja atuação é provocável pelo cidadão, pelas organizações da sociedade civil e por instituições governamentais, como o Ministério Público. $O$ controle legislativo e o jurisdicional são básicos no balizamento da atuação reguladora. Estamos no campo do 'sistema de freios e contrapesos', dos 'checks and balances',". ${ }^{134}$
\end{abstract}

Não vamos abordar neste artigo a analise da repercussão das discussões preliminares sobre o novo marco regulatório brasileiro, ainda impactadas pelo teor político das declarações de autoridades brasileiras no sentido de que o país teria achado um caminho para erradicar a pobreza com as divulgadas descobertas maciças de petróleo na camada do pré-sal. Desde a revelação de tais descobertas, o país está imerso em um intenso debate sobre a melhor maneira de gerenciar sua nova riqueza petrolífera. Em um de seus discursos, o Presidente afirma que tal descoberta simboliza 'a abertura de uma ponte entre a riqueza natural e a erradicação da pobreza. A riqueza advinda da exploração do petróleo será aplicada, primeiramente, na educação e na erradicação da pobreza, criando "infinita e ilimitada riqueza" para o povo brasileiro'. ${ }^{135}$

\footnotetext{
${ }^{132}$ É oportuno destacar que a $10^{a}$ Rodada de Licitação, a mais recente, deu-se sem a inclusão de blocos offshore, o que representou verdadeiro esvaziamento do procedimento, refletido na significativa queda do valor total de bônus de assinatura pago pelos licitantes vencedores em comparação com aqueles obtidos na rodada anterior.

133 OTILLAR, Steven P; MCQUAID, Kristina A., et al. Recent developments in Brazil's oil \& gas industry: Brazil appears to be stemming the tide of resource nationalism. Houston Journal of International Law, vol. 30, n. 2.

${ }^{134}$ FERREIRA, Sérgio de Andréa - Direito da Regulação Econômica: A Experiência Brasileira - Revista Brasileira de Direito Comparado. Rio de Janeiro, 2002, p. 87.

${ }^{135}$ Discurso do presidente Lula proferido num canal televisivo nacional - wire service, Reuters. 07 de setembro de 2008.
} 
Foi criada comissão interministerial para estudar mudanças na Lei do Petróleo e no regime de concessão para a exploração de blocos de alta produtividade, visando a uma maior arrecadação de tributos e royalties. Tal comissão pareceu tomar o papel reservado pela Lei à ANP e ao CNPE. Além disso, identifica-se posição de destaque da Empresa de Pesquisa Energética - EPE, braço executivo do MME, que atuou nas discussões das mudanças legislativas, se responsabilizando por funções legalmente atribuídas à ANP, o que corrobora a nossa impressão de mitigação dos poderes regulatórios próprios da agência reguladora do petróleo.

Vislumbra-se o perigo de que se configure, por parte da comunidade internacional, a percepção de uma emergente cultura de expropriação, no sentido lato. Essa postura, classificada pela extensão contemporânea do conceito de expropriação, se consumada, estaria em desacordo com a principiologia consagrada em nossa Constituição Federal quanto ao papel do Estado na Ordem Econômica.

Ademais, dois pontos muito discutidos, que causaram grande preocupação à comunidade, foram (i) os direitos concedidos em contratos já celebrados e (ii) a possibilidade de criação de uma nova empresa $100 \%$ estatal para gerenciar as reservas de petróleo da camada do pré-sal.

No momento de elaboração do presente estudo, já estão sob análise do Legislativo os Projetos de Lei relativos à disciplina legal do Pré-sal. Tem havido diversos questionamentos formulados por integrantes da indústria e por juristas, amplamente reverberados pela mídia. $\mathrm{O}$ calendário exíguo inicialmente previsto para discussão e votação no Congresso Nacional já foi ultrapassado, mas há ainda muitas incertezas não sanadas pelas propostas. Os privilégios outorgados à Petrobras (operadora necessária com ao menos $30 \%$ de participação em todas as concessões) é passível de questionamento de ordem constitucional, em vista do princípio da impessoalidade e da sujeição das estatais ao regime jurídico próprio das empresas privadas. Da mesma forma, a convivência de regimes distintos (concessão e partilha) em áreas limítrofes pode causar dificuldades técnicas de grande magnitude em caso de necessidade de unitização $^{136}$. Por certo incertezas como essas deverão ser sanadas no processo de debate ora em curso para que não atuem como vetores contrários à atração de investimentos.

O novo marco regulatório pós-descoberta do pré-sal se concretizou com a apresentação dos quatro Projetos de Lei que tratam: da criação da Petrosal e do fundo social,

\footnotetext{
${ }^{136}$ Sobre o assunto veja-se, RIBEIRO, Marilda Rosado de Sá. Uma introdução à unitização de reservatórios petrolíferos. In: RIBEIRO, Marilda Rosado de Sá (org.). Estudos e Pareceres. Direito do Petróleo e Gás. Rio de Janeiro: Renovar, 2005, pp. 115-168.
} 
da instituição do regime de partilha de produção e da cessão onerosa para a Petrobras realizar as atividades de pesquisa e lavra. Não cabem nessas notas comentários mais aprofundados sobre o desenrolar dos debates ${ }^{137}$ - exceto a constatação que de alguma maneira o foco sobre a realocação dos royalties obliterou um sem número de pontos igualmente essenciais para conhecimento pela opinião pública. ${ }^{138}$

O surgimento das empresas independentes no Brasil parecia uma conquista irreversível. Havia dificuldades a serem enfrentadas. No entanto, o dilema das empresas independentes persiste. As dificuldades na venda da produção - com a presença de um único comprador, a complexidade do sistema de certificação do conteúdo local, a ausência de um cronograma de rodadas de licitação para garantir o aumento das reservas das empresas... Esperamos que o novo marco regulatório seja compatível com a continuidade desse novo segmento da indústria, que possibilita a geração de emprego e renda em regiões inóspitas do Brasil desde a realização da $1^{\mathrm{a}}$ rodada de acumulações marginais em 2005

A Lei do Gás (L. 11.909) finalmente sancionada, em 04 de março de 2009, sinalizou um avanço na atração de investimentos para o setor. Todavia, até o presente momento aguarda a regulamentação referida no texto da lei mais de uma dezena de vezes, postergando a aplicação efetiva desse novo instrumento legal.

Por fim, um sinal de que o desenho institucional regulatório está em mutação, no início de dezembro, a diretoria da ANP autorizou a Petrobras a perfurar poço no pré-sal para coleta de informações, em área não concedida, com fundamento na Lei do Petróleo e na Portaria 188/1998 (estabelece as definições para a aquisição de dados aplicados à prospecção de petróleo). Ainda é cedo para avaliar o impacto desta "criativa" medida, que poderia, em alguma medida, ser considerada uma antecipação da ambiência a ser inaugurada do novo marco legal.

Além dos inúmeros desafios tecnológicos e riscos exploratórios que devem ser enfrentados por todos os envolvidos na indústria, há barreiras burocráticas, ideológicas e legais que devem ser superadas. Reduzir a burocracia e fortalecer as regras - seu controle e sua aplicação - é o principal desafio para a melhoria desse cenário. Considerando que o Brasil compete com outros países na captação de investimentos de riscos para a exploração e a produção, o maior desafio do Estado, no âmbito regulatório, é trabalhar melhor na

\footnotetext{
${ }^{137}$ Merece referência obra recém editada, de autoria de Luiz Cesar Quintans e Humberto Quintas A Historia do Petróleo, Rio de Janeiro, Freitas bastos, 2009, que em seu posfácio traz importantes subsídios críticos para a compreensão dos quatro projetos de lei.

${ }^{138}$ Em inúmeras manifestações publicas estados produtores, capitaneados pelo Rio de Janeiro, manifestaram-se críticos contundentes do rumo assumido pelo processo.
} 
manutenção da transparência e da estabilidade institucional, as chamadas "regras do jogo", que tem sido ignoradas a longo prazo. A elaboração da disciplina legal relativa ao Pré-sal parece não fugir a essa regra.

\section{Considerações Finais}

Nestas breves considerações mais uma vez materializou-se nossa visão sobre os desafios presentes para os estudiosos do direito do petróleo, gás e energia. Dentre todos, vale citar a importância dos modelos/padrões internacionais colhidos de Thomas Waelde, em seus escritos prospectivos ${ }^{139}$, nos quais alerta sobre os desafios que eles representam para os advogados da área de energia.

O futuro do direito do petróleo, gás e energia indica novo rumo no plano internacional, plasmado em tratados, contratos e normas de organizações internacionais. Muitas vezes, no plano doméstico, há a tentação de ignorar-se essa produção normativa, sujeita à harmonização das normas jurídicas e ao processo de recepção de direitos. ${ }^{140}$

A evolução doutrinária sobre as candentes questões envolvendo o petróleo no Brasil muito podem se beneficiar da correlação com os recentes desdobramentos do Direito dos Investimentos e das novas perspectivas abrangendo o espaço global, o Direito Cosmopolita e outros.

Temos nos alinhado com as reflexões de novos talentos internacionalistas e administrativistas ${ }^{141}$ que, nos diferentes temas abordados buscam um denominador comum, na busca da segurança jurídica e institucional, mas não de afastando da preocupação com o ideal de justiça e de desenvolvimento e promoção dos direitos humanos.

Dentre essas novas perspectivas, sobressai-se, pelo momento que atravessamos no Brasil, o alerta formulado quanto à fragilidade das normas que não contem com o amplo diálogo com todas as forças da sociedade. Assim a revisão do arcabouço institucional de um

\footnotetext{
139 WAELDE,Thomas, International Standards: A Professional Challenge for natural resources and Energy Lawyers , AMPLA conference, Austrália, em 2004 A menção ao querido amigo constitui aqui homenagem póstuma a esse brilhante jurista e incentivador dos estudos de petróleo, gás e energia em escala mundial.

${ }^{140}$ Nas palavras da Prof ${ }^{a}$ Ana Lúcia de Lyra Tavares, em seu estudo intitulado "O Estudo das Recepções de Direito": “(...) a introdução, em um determinado sistema jurídico, de regras, noções ou institutos pertencentes a um outro sistema.".Ainda, segundo a autora, é preciso observar que os comparatistas consideram as recepções de direito como decorrências naturais dos movimentos de aproximação entre sistemas jurídicos. Encaram-nas como manifestações normais da natureza dinâmica desses sistemas, conferindo-lhe objetivos, no plano interno, de aperfeiçoamento do sistema jurídico nacional, e no plano externo, de harmonização dos padrões jurídicos. In: Estudos Jurídicos em Homenagem ao Prof. Haroldo Valladão, pp. 46-47, e 60.

${ }^{141}$ Entre estes destacam-se, dentre outors, os professores da UERJ Alexandre dos Santos Aragão, Gustavo Binenbojn, Patrícia Baptista e Valter Shuenquener de Araújo, autores de inomeras obras relevantes para a discussão dos investimentos.
} 
setor vital como o petróleo e gás deve ser negociada e permitir a participação além dos diferentes poderes do Estado, dos atores não estatais, a cooperação com organismos multilaterais, junto com a participação ativa do sector privado, das NOCs e da própria sociedade civil. ${ }^{142}$

O mesmo teor da comunidade de responsabilidade destacada pelo Direito Cosmopolita merece então figurar como fecho nessas considerações, com lema de inspiração para a comunidade envolvida com a reflexão sobre a importância do temas dos investimentos, na construção de uma solida e reconhecida Lex Petroleae ${ }^{143}$, e a transcendência dos princípios examinados e seu alcance para a área petrolífera ${ }^{144}$.

142 DEL CORRAL , Amalia Del Carmen Casas de Las Peñas, A Integração Energética na América co Sul: Instrumentos Juridicos e Institucionais para Projetos Gasiferos Regionais tese apresentada como requisito à obtenção ao grau de doutor. Faculdade de Direito UERJ , dezembro 2009. Destacamos o seguinte ponto das conclusões: "O arcabouço jurídico estável, uniforme e confiável não é requisito suficiente, mas sim necessário para se alcançar uma integração energética regional. Sem regras claras e estáveis nem os entes privados nem os próprios Estados conseguem investir em uma integração energética que poderá trazer benefícios e um maior desenvolvimento aos países da América do Sul."

${ }^{143}$ Sobre o tema, vale transcrever passagens alusivas à Lex Petrolea: "O Direito do Comércio Internacional, tendo em vista as suas especificidades, possui também outras fontes, que cumpre-nos aqui referir: as de direito transnacional e de direito nacional. As primeiras, muito contestadas, atuam na ausência de outras normas nacionais, surgindo do esforço dos agentes econômicos internacionais que criam regras próprias de funcionamento de certos setores do comércio internacional, v.g.: "Lex Petrolea", criada pelas grandes multinacionais do setor do petróleo (...). Essas regras, também nascidas da prática, são consideradas de direito transnacional na medida em que são impostas pelos operadores econômicos internacionais sem a participação dos Estados que sentirão os seus reflexos e suportarão seus efeitos.” BASSO, Maristela. Introdução às Fontes e Instrumentos do Comércio Internacional, Revista de Direito Civil, Imobiliário, Agrário e Empresarial, São Paulo, v.20. n.77, jul./set. 1996, p.61

${ }^{144}$ PEDROSO, Jorge. A internacionalização das National Oil Companies e o Direito Internacional. Dissertação de mestrado, UERJ, 2008. 